\title{
Establishing the Contributing Factors to the Resurrection of PIIGS Banks Following the Crisis: A Panel Data Analysis
}

Submitted on $4 / 12 / 18,1^{\text {st }}$ revision $8 / 1 / 19$, accepted $28 / 1 / 19$

\author{
Esteban Miguélez ${ }^{1}$, Jonathan Spiteri ${ }^{2}$, Simon Grima ${ }^{3}$
}

\begin{abstract}
:
In this article, we analyse empirically the factors that allowed for the improvement and strengthening of the banking systems in Greece, Ireland, Italy, Portugal and Spain (known as the PIIGS) during the post-financial crisis period 2011-2016.

We use panel data on 200 banks and measure their financial soundness using the z-score. Our results show that the improvement is mainly due to managerial factors. To ensure stability, banks must monitor their loans and avoid non-performing loans.

The public authorities should try to control banks' size, encouraging medium-sized banks since these tend to perform better on average while limiting the existence of banks, whose size and importance (despite economies of scale) can destabilize the entire system in case of bankruptcy.

Finally, different from previous studies, we include herein the refinancing programmes into the analysis of financial soundness and show that the financial assistance programs have been necessary to ensure the recovery of the banking systems.
\end{abstract}

Keywords: Panel Data, European Banks, PIIGs, Crisis, Banking System.

JEL Classification: 621, G24.

Acknowledgement: We would like to thank Professor I. Lapteacru for his advice when writing this paper

\footnotetext{
${ }^{1}$ University of Bordeaux and University of Malta, est.migact@hotmail.fr

${ }^{2}$ University of Malta, Insurance Department, Faculty of Economics, Management and Accountancy, jonathan.v.spiteri@um.edu.mt

${ }^{3}$ University of Malta, Head Insurance Department, Faculty of Economics, Management and Accountancy, corresponding author, simon.grima@um.edu.mt
} 


\section{Introduction}

During the last decade, European banking systems took a downward economic turn, especially in some south European countries and Ireland, which previously was considered as the model of economic growth in Europe. Their banking systems and more broadly their economies were highly developed and in the constant expansion: for example, in 2007, real GDP growth of these countries stood between 1.4\% (Italy) and $5.2 \%$ (Ireland), paired with high credit growth and supported by a real-estate sector bubble.

After the subprime crisis and ensuing economic slowdown in 2008-09, these countries saw a breakdown of their economic models and a collapse in their banking systems. They had to support significant losses, reporting their illiquid position and for some of them their insolvency. This crisis highlighted the financial weakness of these countries and the importance of a well-functioning financial system to ensure economic growth. This period has been characterized by many bank failures and involved a number of mergers. A bank failure refers to a situation in which the excessively rising liquidity, credit, interest rate, or exchange-rate risk pushes the bank to suspend the internal convertibility of its liabilities. If the bank-failure problem undermines an entire banking system, then the crisis turns out to be systemic. This is what happened in the countries considered in our sample. This weakened the confidence and relationship of/between banks and their customers/banks.

During the period 2000 to 2018 , there was a high level of financial stress in all the countries sampled in this study, specifically Portugal, Ireland, Italy, Greece and Spain, known also as the PIIGS countries (European Central Bank, 2018). To avoid systemic risk, governments bailed-out the banking system, increasing their own debt. Therefore, the financial markets lost trust in these countries (Thalassinos et al., 2012; 2015).

In 2010, these Europeans countries entered a new crisis, the so-called "sovereign debt crisis". The risk-premiums of the States rose until it became very difficult for them to face commitments to creditors, and some faced the risk of default. Greece, for example, could not finance itself on the markets anymore. This risk was passed on to the banking system because of their premium risk since the lender of last resort was also brought close to a default situation. Uncertainty reigned in these sovereign economies. During this period, the banking sectors and the economies were weak and unstable, with very high rates of unemployment, a sharp increase in the cost of borrowing for households as for corporates, an expansion of the ratio "public debt on GDP" and a huge rise in the interest rate on sovereign bonds (European Central Bank, 2018b; Grima, 2012; Grima and Caruana, 2017).

These difficulties in their domestic banking sector and in the public finances forced governments to ask for help from the international community to avoid the risk of insolvency. In response, the international institutions (IMF, ECB, European Commission) intervened to prevent their far-reaching effects on the private sector and 
more generally on the entire economy. The Eurozone created a specific temporary crisis resolution mechanism, called the European Financial Stability Facility (EFSF), which provided financial assistance to Ireland, Greece and Portugal. The goal was to substitute the financial markets, lending money at defined interest rates and especially with very long maturities.

The aim to strengthen these countries was a mandatory step to then improve the banking situation. The eurozone members formed the European Stability Mechanism (ESM), which created a European fund to help countries who need it, but at the same time to reassure the financial markets, encouraging countries to carry out liberal reforms in their economy. These bailouts cost billions of euros and put the receiving countries in a deficit situation for the coming decades.

Nowadays, the recovery of these economies seems to be improving and the expectations of exiting this crisis is rising, driven by the regrowth indicators. These indicators include a declining unemployment rate, coupled with a high increase in credit growth, which seems to have stabilized after the bubble burst. However, borrower soundness can be questioned, and this raises the question of the fundamentals in which the regrowth is taking place and of the long-term sustainability at a macroeconomic level. Nevertheless, regarding the banking systems, the improvement seems to be real. The profitability of banks, measure as the Return on Assets (ROA), appears to increase and become positive or close to zero and above all less volatile (Figure 1).

Our focus in this article is on the evolution of the banking sectors of these five countries since they seem to be at the root of the European crisis and had repercussion on the global economy. It is interesting to understand how the banks in these countries, which were on the verge of an implosion, seem to have become stronger and their balance sheet stabilized. However, the issues are not totally solved, and some weakness remains as shown by the failure of the ECB's stress test by the Italian bank "Monte Dei Paschi" or the bankruptcy of the "Banco Popular" in Spain, purchased last year by the "Banco Santander" for the symbolic price of one-euro.

Figure 1. Return on Assets Per Country. Source: European Central Bank, 2018 Consolidated Balance Sheets - Statistics of The European Central Bank

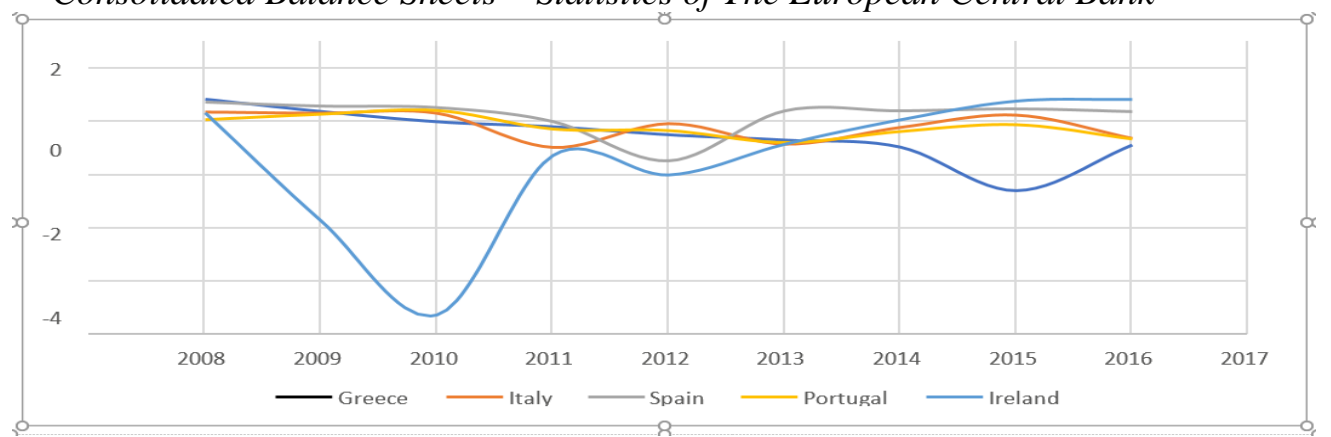


We aim to highlight the determinant factors that have helped to bring the banking system out of this crisis. In doing this, as noted above, we assess the financial soundness of the five European countries (PIIGS) over the period 2011-2016. As a proxy of the financial soundness, we use the 'Z-score' to measure the bank's distanceto-default. This risk measure was derived from the concept of a bank's default probability. We then investigate empirically the endogenous factors of banks and the exogenous factors to each banking sector or to each country and their impact on the zscore. The analysis is conducted in three parts. First on the entire sample with the five countries, then on three of these countries, Italy, Portugal and Spain to highlight their own characteristics. Then we focus on the four countries which have received financial assistance, to highlight the role of these assistance programs in the strengthening of the banking systems.

\section{Literature Review and Hypothesis}

Various authors have tackled the subject of financial soundness and have investigated the determinants of bank's profitability. Some empirical studies are country specific such as that of Trujillo-Ponce (2013,) while others such as Căpraru and Ihnatov (2014) focus on a panel of countries. Although these authors make use of various instruments to measure the financial soundness, we decided to use the traditional measure of the z-score, in accordance with Uhde and Heimeshoff (2008, Demirgüç-Kunt and Huizinga (2001) and Dima et al. (2014) and assume that the return on Assets (ROA) is a random, normally-distributed variable (Lapteacru, 2017). We used the z-score ratio as our proxy to financial default, as a measure of the bank's distance-to-default.

According to previous studies, the factors determining the financial soundness of a banking system fall into three main groups: (1) the determinants specific to each bank, which result from managerial decisions - this group includes asset structure, capitalization, efficiency, size, interest management, financial structure and revenue diversification; (2) factors related to the banking industry of each country, such as the size of this market and the concentration; (3) the macroeconomic environment with such factors as inflation, economic growth and interest rates.

\subsection{Determinants specific to each bank}

At first, we will describe the different independent variables that we use and their previous use in the literature.

2.1.1 Asset structure: To measure the impact of the asset structure on the financial soundness we used loans. Specifically, we took the total of loans, which regroup loans to customers and loans to other banks. A larger proportion of loans in the bank's portfolios is commonly coupled with a greater liquidity risk arising from the incapacity of banks to accommodate decreases in liabilities or to fund increases on the assets side of the balance sheet. The higher the value of loans, the less liquid are the banks. During our period of study, we can observe a wide decrease in the number of loans to 
households and corporates, expected in Italy, after the bubble burst of 2008. The amount of credit seems to stabilize around a pre-crisis level (European Central Bank, 2018).

Trujillo-Ponce (2012), Căpraru and Ihnatov (2014) and also Demirgüç-Kunt and Huizinga (1999) used the loans to take into account the asset structure. According to these previous studies, there is a positive relationship between the relative percentage of loans in the assets and profitability. At the same time, this relative percentage raise the liquidity risk, which can worsen the financial soundness. Therefore, we take the assumption of the ambiguous effects of the asset structure on financial soundness.

2.1.2 Asset Quality: It appears that the banks' soundness is directly related to the quality of the assets, related to credit risk. Poor credit quality should have a negative effect on bank profitability. The subprime crisis with its excess of doubtful mortgage is a good example of this relationship. The relationship between asset quality and profitability is owed to the fact that an increase in doubtful assets requires a bank to allocate a portion of its margin to provision to cover expected credit losses, which will decrease profitability.

De Young and Rice (2003) examine the determinants of the financial performance of US commercial banks, finding a positive relationship between the asset quality and the performance of banks. In contrast, Trujillo-Ponce (2012), in his study on the profitability of Spanish banks, shows a negative relationship between asset quality and profitability. It is argued that, according to Mester (1996), higher loan quality typically implies more resources dedicated to loan monitoring and credit underwriting. Besides this, riskier loans should receive a higher remuneration, which can increase the profitability, but not necessarily the financial soundness of banks. These arguments mitigate our first idea and can let us expect the ambiguous effects of asset quality.

2.1.3 Capitalization: There appears to be a consensus that the cost of equity is one of the most expensive bank liabilities. In the banking literature, it is often argued that higher equity requirements increase funding cost because capital is risky and requires a high return. That could explain why banks managers don't show a high interest to increase it in order to respect capital adequacy as the Basel III accords recommend. Nevertheless, they emphasize that a too high ratio "equity/asset" can be damaging for the banks' financial viability caused by the opportunities costs.

However, there are different reasons to believe that banks with higher equity should be stronger and show higher soundness. Angbazo (1997) just as Berger (1995) show a positive relation between financial soundness and well-capitalized banks. They argued that a well-capitalized bank experiences lower bankruptcy cost according to the bankruptcy cost hypothesis. A bank undercapitalized will face higher cost by higher interest expenses and can expect bankruptcy cost to be relatively high. Abreu and Mendes (2002) also agree on this latter conclusion on. Several empirical studies Bashir (2000), Abreu and Mendes (2002) and Ben-Naceur (2003) highlight that good equity 
adequacy exerts a stimulant effect on bank profitability. The measure of the equity into the balance sheet enables us to consider the insolvency risk.

The literature about capitalization is abundant. Among the different studies, we can mention Berger (1995), Abreu and Mendes (2002), Dima et al. (2014), Căpraru and Ihnatov (2014) and Climent Serrano (2014). Through these studies, we can hypothesize that there is a positive relationship between the amount of a bank's equity and financial soundness.

2.1.4 Financial structure: Banks have different channels to finance themselves. They can have sourced from the wholesale markets or customers deposits. The former gives banks larger flexibility in their financial structure, but they face higher cost, while the latter is a cheap and stable financial resource. Therefore, we herein decide to examine the relationship between customers' deposits and financial soundness. In agreement with Trujillo-Ponce (2013), we can expect a positive relationship between these two features.

Despite this, we raise the questions of the contrary effect. In a situation of "depositwar", banks must attract deposits from competitors which are done through the remuneration of these deposits, increasing the interest rates. The latter has cut bank margins down. Following the beginning of the crisis, most of the banks' premiums of these countries increased. Facing difficulties to access the international funding markets, banks turned themselves to customers' deposits which became essentials. In this context, we can expect a negative relationship between customer deposits and financial soundness. Therefore, given this point, we expect the ambiguous effect of the customers' deposits.

2.1.5 Efficiency: During the last three decades, advances infinancial services and managerial techniques have allowed banks to improve their services most efficiently. As a consequence, the cost to income ratio has been declining. We used this as a proxy for operational efficiency, in agreement with the methods used by Căpraru and Ihnatov (2014) and Trujillo-Ponce (2013). The cost-to-income ratio is commonly used in the banking literature to estimate bank efficiency. It is computed as follows:

\section{Cost-to-income ratio $=$ Operating expenses $/$ Operating Incomes}

Previous studies such as the ones mentioned above find a positive and significant relationship between efficiency and financial soundness. This implies a negative sign for the coefficient of the cost-to-income ratio. The coefficients are mainly very significant, which signify that to strengthen the financial system it is necessary to have operational efficiency. Trujillo-Ponce (2013) argued, in agreement with Berger (1995), that "managerial ability in controlling costs is much more important than economies of scale and scope." Therefore, we examine the relationship between efficiency and financial soundness in our five countries sample. Here we take the 
hypothesis of a positive link between the two previous features.

2.1.6 Size: It is widely argued that the effect of size could be non-linear. In the beginning, the increase of the size will raise the profitability until an inflexion point where the profitability will be declining. That is to suppose medium scale banks are more profitable than smaller or larger banks. Then we can envisage the average cost curve with a flat U-shape, in agreement with Athanasoglou et al. (2008) and De Young and Rice (2003).

At the same time, we must consider economies of scale and scope. A larger size may imply a decrease in costs related to the bank's services. Despite this, Barros et al. (2007) underline that larger banks are more likely to have lower performance, implying that smaller banks can achieve better performance reducing the asymmetric information problems inherent to banking activity. Furthermore, larger banks are prone to take more risk, influenced by the moral hazard argument that they are "too big to fail". In principle, we would expect higher soundness for larger banks which experience higher profitability through the economy of scale. However, as explained above, under a certain threshold, diseconomies of scale can appear which can transform the advantage of size into a disadvantage. Therefore, in agreement with the explanations above, we see the relationship between the size and the financial soundness as ambiguous.

2.1.7 Revenue diversification: As we know, the traditional role of banks has been changing during the past decades. The traditional activities of deposit and lending which consists in making a profit on the interest rates are not the main sources of revenues as before. Banks had been forced to find new sources of revenues to maintain their profitability. Elsas et al. (2010) show that banks moved their activity to diversify their revenues into fee-based businesses. However, this area is subject to strong competition between banks to be attractive to customers. Therefore, they extended their activities into new trading activities, but also by underwriting insurance contracts. This phenomenon is even more bitter in a context of low-interest rate, which puts pressure on the operating margin.

In agreement with Elsas et al. (2010), who state that revenue diversification improves the profitability and then the soundness, increasing the margin from non-interest activities, we decided to make the hypothesis of a positive relationship between the revenue diversification and the financial soundness.

2.1.8 Interest incomes and expenses: We also decided to include in our analysis the impact of the interest expenses and incomes to consider the characteristics of the bank traditional activity. Previous studies consider the interest margin, such as studies by Uhde and Heimesshoff (2009), Demirgüç-Kunt and Huizinga (1999) and Özen et al. (2018). In our study, we separate the interest expenses and the interest incomes to understand better if the improvement of the financial soundness came from an increase of incomes or a decrease in expenses. Knowing that we make the hypothesis of a negative relationship between interest expenses and financial soundness and the opposite hypothesis between interest incomes and financial soundness. 


\subsection{Determinants concerning the banking industry}

2.2.1 Banking Industry concentration and Size: The aim of higher market shares for their banks, lead bankers to have greater benefits owed to the market power. In this way, a more concentrated market will favor banks' profitability. Moreover, a concentrated market means also a lower competition which can increase the benefits from customers' deposits (as mention above in point 2.1.4). Furthermore, as mentioned before, efficiency is very important in reducing the cost structure. Then better-managed banks will see their market shares increase leading to higher concentration. None of the countries of our sample shows a too high market concentration during the period (European Central Bank, 2018). Empirical evidence from Demirgüç-Kunt and Huizinga (2001) but also from Rouabah (2006) and Beckman (2007) show that a lower concentration is assimilated with lower profitability. On the other hand, Berger (1995) find an opposite relation between concentration and profitability. Nevertheless, we decided to make the hypothesis of a positive relationship between concentration and financial soundness. Udhe and Heimeshoff (2009) argued that larger monopolistic banks in concentrated banking markets may reduce financial fragility by providing higher "capital buffers" that can protect them against external chocs. In agreement with these previous studies, we assume of a positive relationship between market concentration and financial soundness.

The size of the banking industry in the whole economy, which measures the shares of the banking in an economy, could be an important determinant of the financial soundness. In agreement with Miguélez (2018) a too wide banking industry can be prejudicial for the financial soundness of the banking system. Then we decide to assume of a negative effect between the size of the banking sector and the financial soundness.

\subsection{Macroeconomics determinants}

In order to capture macroeconomic developments that are likely to affect the bank balance sheet and in turn the financial soundness, we chose the following measures: refinancing interest rates, the GDP per Capita, the rate of real GDP growth, the annual change of inflation and the interest rate on sovereign bonds.

2.3.1 Inflation: The measure of inflation is commonly used in the analysis of the financial soundness of the banking systems. There is a financial nexus between banks profitability and inflation. Inflation can affect banks costs, as the salaries. Furthermore, inflation is very important for banks and their management of the interest rate. This factor is probably associated with the higher realization of net interest margins. If the inflation is fully anticipated, banks managers will transmit it to the interest rates. If the latter is adjusted accordingly, the bank can increase revenues faster than cost, which should be beneficial for the profitability (Trujillo-Ponce, 2013). In the case of partial anticipation of inflation, banks can expect losses. Using the 
assumption that bank have good anticipation of inflation, we make the hypothesis of a positive relationship between inflation and financial soundness, congruent with Uhde and Heimeshoff (2009), Capraru and Ihnatov (2014) and Dima et al. (2014).

2.3.2 GDP Growth: The rate of growth of the GDP is a control variable since the banks' investment opportunities may be correlated with business cycles. Under an economic boom, all sectors of the economy are growing including the banking industry. Therefore, investment opportunities should arise. This slope of the cycle is commonly related with an increase of credit demand. Moreover, borrowers' solvency may be higher which improves assets quality. In agreement with most of the previous banking literature on financial soundness, Uhde and Heimeshoff (2009), TrujilloPonce (2013), we make the hypothesis of a positive relation between financial soundness and the rate of growth of the GDP.

2.3.3 GDP per Capita: In order to capture the wealth of the country and its development, we decided to include GDP per capita, which serves as a proxy for income per head within a country. This measure seems to be more realistic than just the measure of the GDP, which can increase in value but decrease in value per capita and will fluctuate according to country size. This measure has been previously used in different articles such as those by, Udhe and Heimeshoff (2009) and Căpraru and Ihnatov (2014). We expect a positive relationship between this measure of the development and the financial soundness in banking systems.

2.3.4 Interest rates: The interest rates are divided into two parts. The interest rate on refinancing operation for banks, and the interest rate on the sovereign bonds, which affect the banking interest rates.

2.3.4.1 Interest rate on banking refinancing operation: Nowadays European banks perform in a context of low-interest rates. Coupled with a high rate of competition, banks are limited to set the appropriate rates on their credits and deposits. As explained above (see part 2.1.7), this creates pressure on the operating margin of banks. Despite this, Demirgüg-Kunt and Huizinga (1999), Molyneux and Thornton (1992) and Trujillo-Ponce (2013) highlight that there is a positive relationship between interest rate and profitability, hence financial soundness too. In agreement with these authors, we do the hypothesis of a positive relationship between the interest rate and the financial soundness.

2.3.4.2 Interest sovereign rate: We decided to use another interest rate concerning the sovereign debt. In Spain, in May 2012, the government announced a debt-financed recapitalization of the undercapitalized Spanish banking system. Both banks' CDS and sovereigns' CDS increased higher than was expected when for the former a decrease was expected. Recapitalized banks faced higher CDS while higher sovereign debt discount deteriorated the fiscal position of the Spanish government (Van der Kwaak and Van Wijnbergen, 2017). In agreement with this event, we decide to add the interest rate on sovereign bond to our analysis. Moreover, as explained in the previous part, 
there is a relation between the sovereign soundness (which can be measured through the interest rate on sovereign bond) and the financial soundness. In agreement with that, a negative relationship between the interest rate on sovereign bonds and financial soundness of banking systems is expected. If the situation of a country deteriorates (increase in the sovereign interest rates), the situation of banks will too (decrease in the financial soundness).

2.3.4.3 Bailouts: This period in the Eurozone has been characterized by several assistance programmes for different countries, including four countries in our sample, Greece, Ireland, Portugal and Spain. Get trapped into the financial crisis and then into the sovereign debt crisis, these countries asked for international help. IMF and the European institutions came to rescue these countries under specific conditions regarding their economies. In June 2010, the European institutions created the European Financial Stability Facility (EFSF), as a temporary crisis resolution mechanism by euro area countries. The assistance was financed via bonds and other debts instruments on capital markets. Nowadays, most of the programmes are still in the application, or at least these countries continue to repay the loans. We include the refinancing programmes into the analysis of financial soundness. The expected relationship between the refinancing programs and the financial soundness is a positive relationship, as these programmes were made to strengthen the financial sector. Empirical Analysis

\subsection{Data Captured}

2.4.1 Sample: We use yearly data for 200 banks from five countries of the eurozone Greece, Ireland, Italy, Portugal and Spain for the period 2011-2016. We eliminated banks for which less than four consecutive year data was available and the ones for which information wasn't available for all of the variables analysed. Our Banks' balance sheet data was collected using Bankscope.

2.4.2 Dependent variable: $\mathrm{We}$ use as the dependent variable the z-score ratio. We employ it as a measure of the bank's distance to default, which is our proxy for the financial soundness. "This risk measure was conceived from the concept of a bank's default probability" Lapteacru (2017). The z-score ratio is computed as follows:

$$
\text { z-score }=\frac{\mathrm{CAR}+\mathrm{E}(\mathrm{ROA})}{(R \mathrm{OA})}
$$

where CAR is the capital on assets ratio and ROA the return on assets. $\mathrm{E}(\mathrm{ROA})$ represents the expected value of ROA and $\sigma(R \mathrm{OA})$ the standard deviation of ROA. We are conscious of the shortcoming owed to this measure of the traditional z-score raised by Lapteacru (2016). Therefore, we assume of normal distribution for ROA.

2.4.3 Independent variables: Our aim is to analyse which determining factors allow the strengthening of the banking systems of our sample during our period of 
study. As mentioned in section II, banking literature considers three categories of factors that determine bank's soundness: bank-specific factors (loans, size, financial structure, credit risk, bank efficiency, bank capitalization, revenue diversification, liquidity risk, capital structure) ; industry-specific (concentration, size of the banking industry) ; and macroeconomic factors (inflation, rate of growth of real GDP, GDP per capita, interest rates).

To analyse the effect of the asset structure on the financial system of the banking systems we use loans to total assets ratio. We considered it as a proxy of the liquidity, which indicates the shares of the loans into the total asset structure. The higher the value of this ratio, the less liquid the bank. Nonetheless, a higher ratio should increase profitability but also increase the liquidity risk. We carry out a linearization of this ratio through the logarithm function.

To analyse whether the effect of asset quality on financial soundness is positive or negative we use the loan loss provision. This feature gives us the provision for impairment losses in the banks' portfolios. An increase in this value indicates a worsening in the quality of the loan assets, which correspond to lower asset quality. The natural logarithm is used to measure the asset quality.

In order to examine whether the capitalization of banks is a determining factor of financial soundness, we use the equity to total assets ratio. This ratio is commonly used is the banking literature as it gives the proportion of equity in the balance sheet in order to measure the capitalization. Our expectations are that a higher capitalization should be coupled with higher financial soundness. As for the previous variables, we use the logarithm function.

To analyse the effect of the financial structure, as mentioned above, we use the customer deposits, but as a ratio using the total assets as the denominator. We know that customer deposits represent a stable and not expensive resource compared with other financial alternatives, however, a "deposit war" context could be detrimental for the bank strength. Hence, we do the hypothesis of an ambiguous relation with our dependent variable. The customer deposit is also linearized through the logarithm function.

As a proxy of the efficiency in banks, we use the cost to income ratio, to see if banks that are more efficient have higher soundness. This ratio is the relation between operating expenses and operating incomes. This ratio measures the running cost as a percentage of income.

As it is commonly used in the banking literature, we use the natural logarithm of the total bank assets as a proxy of the size of the bank. For the reasons mentioned above, the economies of scale which can turn in diseconomies in case of too large banks, which are not as easy to manage as medium or smaller banks. We expect ambiguous effects of the size on financial soundness. 
To measure the characteristics referring to the effect of diversification of income we use the natural logarithm of the ratio "non-interest income / operating revenues". We use it in order to capture the transformation operated by banks in their activity to diversify income.

Finally, to measure the last of the bank-specific characteristics, the interest incomes and expenses we use for the former the ratio interest incomes on average interestearning liabilities asset, and for the latter the ratio interest expenses on average interestbearing liabilities. Both are log-linearized.

Several measures of the banking concentration are usually used in the banking literature. We can mention the Herfindahl-Hirschman Index (HHI) industry concentration or the shares of the five largest banks in the banking industry of each country. An easier measure, which can be also used, is the ratio of banks' total assets on the banking industry total assets. We did regression with these three measures of the concentration. After different analysis, we decided to keep the HHI measure, which presents the best results and the fewer shortcomings. This measure seems also to be the most commonly used in the literature to measure concentration. The statistics of the European Central Bank provide a measure of this index.

In order to estimate the effect of the size of the banking industry on the financial soundness, we compute the ratio of banking industry total assets on GDP. Data of banking industry total assets was downloaded from the Datastream (Eikon) platform. The GDP data was downloaded from the World Development Indicators (WDI) provided by the World Bank.

The first macroeconomics-determining factor used is inflation. We measure its effect through the annual inflation rate (GDP deflator). As discussed previously, we expect a positive effect between the inflation and our dependent variable. We extract these data from the database of the World Development Indicators.

As mentioned in the literature reviews, we decide to include the growth rate of the real GDP (Gross Domestic Product). We expect a positive effect of the GDP growth on the financial soundness. Additionally, in our study, we use the GDP per Capita, which could be a more realistic measure of the economic growth in a country and of the wealth. Both indicators come from the WDI database.

To analyse whether the way in which the quantity of liquidity affects the financial soundness of the banking system we use the interest rate on the main refinancing operations (MRO) of the European Central Bank. In addition, to test the hypothesis that the sovereign debt has a negative relationship with the financial soundness, we use the interest rate on 10-year sovereign bonds in each country, provided by Datastream (Eikon). For the latter measure, we use the log-linearization function.

For the third part of our analysis where we try to highlight the effects of the financial 
assistance, we include this measure taking the data from the European Stability Mechanism web page. As amounts come in tranches and we use annual data, we take the sum of the amount received per year. We use the natural logarithm for the measure to avoid non-linearity.

\section{Methodology}

We first, carry out simple OLS regressions on the bank-specific factors and then add the industry and macroeconomic factors. As our study is based on panel data, we carry out a fixed-effect regression and then a random-effect regression. Following the analysis, we proceed to a Hausman test, in order to find the specialization of the model. We estimate the following equation:

$$
\begin{aligned}
& Y_{i, t}=\alpha+\beta 1 \cdot \ln (\text { Loans } / T A)_{i, t}+\beta 2 \cdot \ln (\text { loan loss provision } / T A)_{i, t} \\
& +\beta 3 \cdot \ln (\text { Equity } / T A)_{i, t} \\
& +\beta 4 \cdot \ln (\text { customer deposits } / T A)_{i, t}+\beta 5 \cdot \text { cost to } \text { income }_{i, t} \\
& +\beta 6 \cdot \text { size }_{i, t}+\beta 7 \cdot \text { Non operating income/Operating revenues }{ }_{i, t} \\
& +\beta 8 \cdot \ln \left(\text { int }_{\text {inc }}\right)_{i, t}+\beta 9 \cdot \ln \left(\text { int }_{\text {exp }}\right)_{i, t}+\delta 1 \cdot H H I_{t}+\delta 2 \cdot \text { size sector }_{t} \\
& +\gamma 1 \cdot \ln \left(\text { growth real GDP }_{k, t}+\gamma 2 \text { inflation }_{k, t}+\gamma 3 \cdot \text { GDP } \text { Capita }_{k, t}\right. \\
& +\gamma 4 \cdot \text { interest bonds } s_{k, t}+\gamma 5 \cdot M R O_{t}+v_{i, t}+\varepsilon_{i, t}
\end{aligned}
$$

Here, subscripts $i, k$ and $t$ index banks, countries and time in years, respectively, represents the $\mathrm{z}$-score ratio as our measure of financial soundness. $\beta$ coefficients are related with the bank-specific factors, $\delta$ coefficients with the industry-specific factors and $\gamma$ with the macroeconomic factors. $\varepsilon_{i}$, is an error term. The component $\mathrm{V}$ captures the remaining disturbance that is assumed to be uncorrelated over time. TA represents the banks' total assets.

Table 1. Explanatory Variables and Expected Signs

\begin{tabular}{|l|l|c|}
\hline Explanatory Variables & Description & $\begin{array}{c}\text { Expected } \\
\text { signs }\end{array}$ \\
\hline Bank-Specific factors: & \multicolumn{2}{|l|}{} \\
\hline Total loans / Total & Measure of the asset & $(+/-)$ \\
\hline Loan loss provision / & A measure of the & $(+/-)$ \\
\hline Equity / Total assets, log & Capitalization & $(+)$ \\
\hline Customer deposits / Total & A measure of the & $(+/-)$ \\
\hline The cost to income ratio & A measure of the & $(-)$ \\
\hline Total assets, log & A measure of the size & $(+/-)$ \\
\hline Non-interest income / & Revenue & $(+)$ \\
\hline $\begin{array}{l}\text { Interest income / Average } \\
\text { interest earning assets, }\end{array}$ & $\begin{array}{l}\text { Measure the interest } \\
\text { revenue }\end{array}$ & $(+)$ \\
\hline
\end{tabular}




\begin{tabular}{|l|l|c|}
\hline $\begin{array}{l}\text { Interestexpense/Average } \\
\text { interest bearing } \\
\text { liabilities, log }\end{array}$ & $\begin{array}{l}\text { Measure the interest } \\
\text { expenses }\end{array}$ & $(-)$ \\
\hline Banking industry factors: & \multicolumn{2}{|l|}{} \\
\hline Herfindahl-Hirschman & A measure of the & $(+)$ \\
\hline Banking Industry total & Size of the sector & $(-)$ \\
\hline Macroeconomic factors: & \multicolumn{2}{|l|}{} \\
\hline GDP deflator, \% & Measure the inflation & $(+)$ \\
\hline Rate growth real GDP, \% & Measure the Economic & $(+)$ \\
\hline GDP per capita & Measure the wealth & $(+)$ \\
\hline Rate main refinancing & Measure the cost of & $(+)$ \\
\hline The interest rate on & Measure the cost of & $(-)$ \\
\hline Bailouts, log & Measure the effect of & $(+)$ \\
\hline
\end{tabular}

During our analysis, we proceed to a Breusch-Pagan test with the aim to highlight heteroscedasticity. The banking literature predicts heteroscedasticity in banking analysis in panel data, and heteroscedasticity has been detected in our analysis. In keeping with that, we do a Wooldridge test to highlight the first-order autocorrelation, which is inherent to panel data analysis. In order to deal with the autocorrelation, we use the function "xtregar" which "fits cross-sectional time series regression models when the disturbance term is first-order autoregressive" (Manual 13 Stata). As a robustness test, we implement the generalized method of moments (GMM) estimator developed by Arellano and Bover (1995) and Blundell and Bond (1998). We do it in order to avoid endogeneity and to corroborate our finding. Moreover, the systemGMM estimator provides a Sargan test to detect over-identification. We estimate the following equation for the GMM estimator:

$$
\begin{aligned}
& Y_{i, t}=\alpha+\beta 0 \cdot Y_{i, t-1}+\beta 1 \cdot \ln (\text { Loans } / T A)_{i, t}+\beta 2 \cdot \ln (\text { loan loss provision } / T A)_{i, t} \\
& +\beta 3 \cdot \ln (\text { Equity } / T A)_{i, t} \\
& +\beta 4 \cdot \ln (\text { customer deposits } / T A)_{i, t}+\beta 5 \cdot \text { cost to income } i, t \\
& +\beta 6 \cdot \text { size }_{i, t}+\beta 7 \cdot \text { Non operating income/Operating revenues }_{i, t} \\
& +\beta 8 \cdot \ln \left(\text { int }_{\text {inc }}\right)_{i, t}+\beta 9 \cdot \ln \left(\text { int }_{\text {exp }}\right)_{i, t}+\delta 1 \cdot H H I_{t}+\delta 2 \cdot \text { size sector }_{t}
\end{aligned}
$$

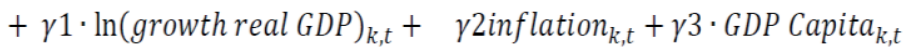

$$
\begin{aligned}
& +\gamma 4 \cdot \text { interest bonds } s_{k, t}+\gamma 5 \cdot M R O_{t}+\varepsilon_{i, t}
\end{aligned}
$$

As mentioned above we carry out an OLS regression for all the sample, and then for our three specifics countries. We do the same regarding the sample of the countries which benefit from the assistance programmes, including these programmes into the analysis. There are two OLS regressions, one regarding the bank-specific factors and then all the factors including the banking industry ones and the macroeconomic factors. 
Then we carry out a fixed effects regression with temporarily and individuals' effects. On the other hand, we carry out a random-effects regression. Then, in order to choose the specialization of the model we implement a Hausman test. In our case, and not totally in agreement with the literature, we find the random effect in our regressions. Uhde and Heimeshoff (2009) found the same effect in their previous study.

In order to test for heteroskedasticity, we carry out a Breuch-Pagan test, which has been detected. In addition, we also carry out a Wooldridge test for autocorrelation, which indicates the presence of first-order serial correlation within each panel. Therefore, we use cluster-robust standard errors in our analysis in order to correct for both heteroscedasticity and autocorrelation.

Finally, to improve our analysis, and to deal with endogeneity and autocorrelation, we carry out a system GMM estimator, keeping in mind the usual shortcomings, which may occur with a sample of five countries.

\section{Results}

\subsection{Entire sample analysis}

We present the main empirical results in Table 2. Regression (1) is the first OLS estimator including bank-specific factors. Regression (2) reports results assessing the impact of banking industry factors and macroeconomic factors on the financial soundness as measured by the z- score technique. Regression (3) is the robust randomeffect regression, specified by the Hausman test, using the same factors of regression (2). Finally, as a robustness check, we have the regression (4), which uses a systemGMM estimator.

4.4.1. Main findings: As we are carrying out an empirical analysis on panel data, we focus on the interpretation of the results of regression (3), corresponding to the robust random-effects regression, presented in Table 2.

The ratio loans on total assets represent our proxy for the asset structure. As explained in section 2 and in agreement we the previous literature, our expectations are ambiguous. An increase in the ratio can improve the profitability of banks, but at the same time increase the liquidity risk. Our results give us a significant, at $1 \%$, and a negative relationship with the z-score, which agrees with the findings of DemirgüçKant and Huizinga (1999). Despite increasing the profitability, the increase of this ratio deteriorates the financial soundness of the banking system. Then we can conclude that the resurrection of the banking system of our sample is not supported by an increase of the shares of the loans in the total asset. This period is characterized by a decrease in the total of loans in the countries (Figure 1). 
Table 2. Determinants of the Banks Resurrection in the whole Sample

\begin{tabular}{|c|c|c|c|c|}
\hline VARIABLES & $\begin{array}{c}\text { (1) } \\
z \text {-score }\end{array}$ & $\begin{array}{c}(2) \\
z-\text { score }\end{array}$ & $\begin{array}{c}\text { (3) } \\
z-\text { score }\end{array}$ & $\begin{array}{c}\text { (4) } \\
z \text {-score }\end{array}$ \\
\hline$z$-score $(t-1)$ & & & & $\begin{array}{l}0.165^{\cdots} \\
(0.072)\end{array}$ \\
\hline Total Loans & $\begin{array}{c}-0.086 \cdots \\
(0.034)\end{array}$ & $\begin{array}{c}-0.110^{\prime} \\
(0.032)\end{array}$ & $\begin{array}{c}-0.112 \cdots \\
(0.043)\end{array}$ & $\frac{0.181}{(0.072)}$ \\
\hline Loan loss provision & $\begin{array}{l}0.258 \\
(0.023)\end{array}$ & $\begin{array}{c}-0.238 \\
(0.022)\end{array}$ & $\begin{array}{l}0.267 \\
(0.025)\end{array}$ & $(0.045)$ \\
\hline Equitsy & $\begin{array}{c}0.230 \cdots \\
(0.037)\end{array}$ & $\begin{array}{c}0.232 \cdots \\
(0.036)\end{array}$ & $\frac{293 \cdots}{(0.045)}$ & $\begin{array}{c}0.670 \cdots \\
(0.076)\end{array}$ \\
\hline Customer deposits & $\begin{array}{l}0.056^{-} \\
(0.032)\end{array}$ & $\begin{array}{c}0.076 \cdots \\
(0.030)\end{array}$ & $\begin{array}{l}0.210^{*} \\
(0.085)\end{array}$ & $\begin{array}{c}-0.355 \cdots \\
(0.073)\end{array}$ \\
\hline Cost to income ratio & $\begin{array}{c}0.011 \\
(0.001)\end{array}$ & $\begin{array}{c}0.011 \\
(0.001)\end{array}$ & $\begin{array}{c}0.010^{2} \\
(0.001)\end{array}$ & $\begin{array}{c}-0.005 \cdots \\
(0.001)\end{array}$ \\
\hline Size & $\begin{array}{c}0.476 \\
(0.058)\end{array}$ & $\begin{array}{c}-0.396 \cdots \\
(0.056)\end{array}$ & $\begin{array}{c}0.603 \\
(0.069)\end{array}$ & $\begin{array}{c}-1.338 \\
(0.160)\end{array}$ \\
\hline Non interest income & $\begin{array}{l}-0.004 \\
(0.047)\end{array}$ & $\begin{array}{c}0.071 \\
(0.045)\end{array}$ & $\begin{array}{l}-0.067 \\
(0.054)\end{array}$ & $\begin{array}{l}0.287^{\circ} \\
(0.152)\end{array}$ \\
\hline Interest incomes & $\begin{array}{l}0.064 \% \\
(0.035)\end{array}$ & $\begin{array}{c}0.320 \cdots \\
(0.041)\end{array}$ & $\begin{array}{c}0.156 \cdots \\
(0.047)\end{array}$ & $\begin{array}{l}0.295= \\
(0.115)\end{array}$ \\
\hline Interest expenses & (0.028) & $\begin{array}{c}-0.129 \\
(0.104)\end{array}$ & $\begin{array}{l}-1.345 \\
(0.832)\end{array}$ & $\begin{array}{l}-0.053 \\
(0.108)\end{array}$ \\
\hline HHI & & $\begin{array}{c}1.700 \\
(3.103)\end{array}$ & $\begin{array}{c}8.916 \cdots \\
(2.578)\end{array}$ & $\begin{array}{c}13.482 \\
(4.923)\end{array}$ \\
\hline Sector Size & & $\begin{array}{c}-1.060 \\
(0.230)\end{array}$ & $\begin{array}{l}0.574 \cdots \\
(0.214)\end{array}$ & $(0.244)$ \\
\hline Inflation & & $\begin{array}{c}-0.410^{\prime} \\
(0.060)\end{array}$ & $\begin{array}{c}0.173 \cdots \\
(0.049)\end{array}$ & $\begin{array}{c}-0.171 \\
(0.092)\end{array}$ \\
\hline Growth GDP & & $\begin{array}{c}0.164 \cdots \\
(0.029)\end{array}$ & $\begin{array}{c}0.002 \\
(0.018)\end{array}$ & $\begin{array}{c}0.022 \\
(0.039)\end{array}$ \\
\hline GDP per Capita & & $\begin{array}{c}-1.046 \cdots \\
(0.410)\end{array}$ & $\begin{array}{l}0.282 \\
(0.299)\end{array}$ & $\begin{array}{c}0.030 \\
(0.329)\end{array}$ \\
\hline MRO & & $\begin{array}{c}1.227 \\
(0.230)\end{array}$ & $\begin{array}{l}0.341 \\
(0.185)\end{array}$ & $\begin{array}{c}0.415 \\
(0.382)\end{array}$ \\
\hline 10-years Bonds & & $\begin{array}{l}0.860^{\prime} \\
(0.201)\end{array}$ & $\begin{array}{c}-0.3140 \\
(0.154)\end{array}$ & $\begin{array}{l}-0.285 \cdots \\
(0.144)\end{array}$ \\
\hline Constant & $\begin{array}{l}0.829 \cdots \\
(0.211)\end{array}$ & $\begin{array}{c}-1.959 \\
(6.270)\end{array}$ & $\begin{array}{c}-9.407 \% \\
(4.434)\end{array}$ & $\begin{array}{l}-7.842 \\
(5.169)\end{array}$ \\
\hline $\begin{array}{l}\text { Observations } \\
\text { R-squared }\end{array}$ & $\begin{array}{l}892 \\
0.394\end{array}$ & $\begin{array}{c}892 \\
0.487\end{array}$ & $\begin{array}{c}892 \\
0,423\end{array}$ & 776 \\
\hline Number of bankname1. & & & 192 & 189 \\
\hline
\end{tabular}

The analysis of the asset quality through the loan loss provision yields significant results. Our finding assumes that there is a negative relationship between loan loss provision and financial soundness, which corroborate the findings of Udhe and Heimesshoff (2009) and Trujillo- Ponce (2013). Our hypothesis about this characteristic was ambiguous. Firstly, we argued that the relationship was negative, knowing that an increase in the doubtful assets requires to allocate a higher portion of margin to provision to cover the expected losses. We mitigate our reflection considering the contribution of Trujillo-Ponce (2012) and Mester (1995) who explain that higher quality loans imply more resources dedicated to loans monitoring and credit underwriting. Even if this last argument can, in fact, increase profitability, we show that the deterioration of the asset quality is a burden for the restructuring of banks. Moreover, the five countries of our sample were exposed to a high and strong increase of non-performing-loans (see appendix 5 Figure), which can justify the implementation of rigorous loans monitoring.

Our next finding relates to the capitalization of banks. In agreement with our hypothesis, there is a positive and significant relationship between the bulk of equity and financial soundness. Therefore, our findings are in line with the evolution of the Basel agreement, which requires an increase in bank capitalization to avoid banking 
fragility. A higher level of equity makes banks, and then the whole banking system stronger. However, it must be highlighted that a too high level of capitalization can lead to decrease the efficiency because of the opportunity cost. This finding agrees with the banking literature, among these findings are Căpraru and Ihnatov (2014), Trujillo-Ponce (2012), Petria et al. (2015), Demirgüç-Kant and Huizinga (1999).

As expected, the cost to income ratio has a significant negative impact on the financial soundness, even if it is very low. This finding indicates that the operational efficiency on cost has a positive impact on banks' financial soundness. This result agrees with the literature as shown by Uhde and Heimeshoff (2009) and Căpraru and Ihnatov (2014). This finding allows us to state that an improvement of operational efficiency is necessary to improve financial soundness.

The coefficient of the banks' size provides us with an interesting result. We find a negative and significant relationship between banks' size and financial soundness. In spite of the economies of scale, it seems that larger banks show higher fragility. That can be due to the average cost curve with a U-shape, as explained by Athanasoglou et al. (2008) and De Young and Rice (2003). Moreover, larger banks can achieve lower performance than medium and smaller banks because they cannot reduce the asymmetric information as well (Barros et al., 2007).

Regarding the interest expenses and incomes, results seem to agree with our hypothesis. The interest incomes have a positive significant relationship with the $\mathrm{z}-$ score measure, which predicts that the strength of banks is backed by interest income. On the other hand, the interest expenses show a negative sign but don't have any significant level.

The ratio of customer deposits to total assets gives us a way to analyze the financial structure of the balance sheet. As we explain above, and in agreement with the previous literature, we expect ambiguous results for this factor. Despite that customer deposits are cheap and stable in a context of "deposit war", in order to attract deposits, banks can cut their margins. Our empirical analysis provides us with a positive, and significant, at a 5\% level, the relationship between customers' deposit and the z- score. That means that stable and cheap financing in a case of financial instability plays a significant part in the recovery of the banking systems. Then, we can deduce that the customers' deposits reinforce the banks' financial structure and helped to make them stronger. As a measure of the concentration, we use, as explained above, the HHI. We find a highly significant and positive relationship with the financial soundness, which shows that a more concentrated banking industry have, fewer weaknesses than a non-concentrated market.

About the relationship between concentration and financial soundness, the banking literature is split in two. Our findings agree with the study by Beck et al. (2006) but in disagreement with the empirical research of De Nicolo et al. (2004) and Uhde and Heimeshoff (2009) who find a negative relation. However, we can assume that a more 
concentrate industry may enhance profits and reduce financial fragility by providing "capital buffer" that protect them in case of externalchocs.

The second banking industry indicator is size. It appears to have a negative role in financial soundness, with a negative and significant coefficient. We can interpret that if the banking industry is too important compared with the rest of the economy there is a higher risk of financial soundness. The evolution of the banking industry must keep in line with the evolution of the economy. If the banking industry grows more than the economy, we can then expect a misalignment with the real economy.

Regarding the global factors, results are not as revealing as the bank-specific factors. Firstly, the GDP factors, the growth of GDP and the GDP per capita are admittedly positive but not significant at all. Concerning the GDP per capita, Uhde and Heimeshoff (2009) and Căpraru and Ihnatov (2014) also found non-significant results, which is corroborated by our study contrary to Demirgüç-Kant and Huizinga (1999) who find a strong and positive relationship. Nevertheless, regarding the rate of real GDP, Trujillo-Ponce (2013) find a significant and positive relationship contrary to Demirgüç-Kant and Huizinga (1999) who find a non-significant relationship.

We initially set out the hypothesis of a positive relationship between inflation and financial soundness. Our results show us an inverse relationship, which is significantly negative at the $1 \%$ level. This result is not in agreement with the main literature by Trujillo-Ponce (2013), Miguélez (2018) and Căpraru and Ihnatov (2014), which predicts a positive relationship. Nevertheless, Uhde and Heimeshoff (2009) also find a negative relationship between inflation and financial soundness. Then, we suppose that the banks in our sample do not fully anticipate the inflation, which impacts their profitability and thus their financial soundness.

As a proxy for interest rates, we use the interest rate on the main refinancing operations (MRO). We make the hypothesis of a positive relationship with our dependent variable, and our result corroborates it, albeit only at the $10 \%$ level. The period of the study is characterised by an environment of low interest rates, with a constant decrease of the MRO (see appendix 3 Figure).

We can make the hypothesis that in this context, banks take advantage of this environment to increase their soundness, even if some previous literature argue that banks couldn't establish the appropriate prices for their loans and deposit as suggested by Trujillo-Ponce (2013). Despite this, our findings agree with the banking literature, which reports a positive association as per Demirgüç-Kunt and Huizinga (1999) results. Our last macroeconomic factor is the interest rate on the 10-year sovereign bond. The result regarding this factor agrees with our hypothesis. We find a negative relationship between the interest rates on sovereign bond and financial soundness. That implies a strengthening financial system linked to a stable situation for the country. If markets expect higher risk for countries, there will be a decrease in the financial soundness and vice versa. Healthy finances for the government is required 
to strengthen the banking system. Interest rates on a bond of each country are presented in figures Appendix 4. Moreover, in the countries where the state has the role of "lender of the last resort" a healthy financial system is required to set the credibility of this role. This finding agrees with the results of Molyneux and Thornton (1992).

As explained above we also estimate a GMM system, as a robustness check and to deal especially with endogeneity. The findings are broadly consistent with those obtained above. Coefficients show the same signs and almost always the same significances levels. Notice that there are few differences. The coefficient of the customers' deposits become negative and highly significant with this new regression.

This can mean that the "deposit-war" conducted by the banks could have been harmful to their financial soundness, competing "too hard" between them to get more deposits. The non- interest incomes show a negative coefficient but contrary at the previous regression it becomes significant but at a weak level of $10 \%$, which indicates that revenue diversification could have been detrimental. Regarding inflation, the coefficient isstill negative but only weakly significant. The GMM test provides a Sargan test, which tests the hypothesis of over-identified restrictions. The result gives us a pvalue of 0.864 , which means that we cannot reject the null hypothesis that our overidentifying restrictions are valid.

\subsection{Analysis conduct on specific countries (Italy, Portugal and Spain)}

As for the entire sample, we first run two OLS regressions, the first one with bankspecific factors and then with all the factors included. We then run another two regressions, one with Fixed Effects and one with Random Effects, using cluster-robust standard errors. To specify our model, we use a Hausman test. As previously, a GMM estimator is implemented as a robustness check.

4.5.1 Main Results for Italy: We present the main results for Italy in Table 3. As in the regression of the whole sample, the Hausman test suggests that the Random Effects model should be employed. Our findings are like the previous analysis. We will discuss the key factors, while also presenting the main differences. The improvement of the Italian banking system does not seem to be supported by the customers' deposits. In fact, this factor becomes non-significant in the analysis of the Italian banks. The financial structure of these banks can be based on stable financing, but it does not seem to strengthen the banking industry.

Regarding the interest expenses and income, there appear to be some differences. The interest expenses have a negative sign as expected and are strong significance contrary to our first analysis. This means that the interest expenses had some play in the strong and negative role in making the Italian banking system better. 
Table 3. Determinants of the Banks Resurrection in Italy

\begin{tabular}{|c|c|c|c|c|}
\hline VARIABLES & $\begin{array}{c}\text { (1) } \\
z-5 c o r e\end{array}$ & $\begin{array}{c}(2) \\
z-5 c 0 r e\end{array}$ & $\begin{array}{c}\text { (3) } \\
\text { z-score }\end{array}$ & $\begin{array}{c}\text { (4) } \\
z \text {-score }\end{array}$ \\
\hline$Z$-score $(t-1)$ & & & & $\begin{array}{c}0.715^{* 07} \\
(0.102)\end{array}$ \\
\hline Total Loans & $\begin{array}{c}-0.151 \cdots \\
(0.039)\end{array}$ & $\begin{array}{c}-0.151 \cdots \\
(0.039)\end{array}$ & $\begin{array}{c}-0.147 \cdots \\
(0.050)\end{array}$ & $\begin{array}{c}-0.337 \\
(0.088)\end{array}$ \\
\hline Loan loss provision & $-0.237 \%$ & $\begin{array}{c}-0.237 \\
(0.028)\end{array}$ & $\begin{array}{c}-0.265 \cdots \\
(0.031)\end{array}$ & $\begin{array}{l}-0.420^{\circ} \\
(0.074)\end{array}$ \\
\hline Equity & $0.443^{0.0 .}$ & $\begin{array}{c}0.443^{\cdots \cdots} \\
(0.055)\end{array}$ & $\begin{array}{c}0.458 * \cdots \\
(0.064)\end{array}$ & $0.686 \cdots$ \\
\hline Customer deposits & $\begin{array}{c}0.062 \\
(0.050)\end{array}$ & $\begin{array}{c}0.062 \\
(0.050)\end{array}$ & $\begin{array}{c}0.092 \\
(0.063)\end{array}$ & $\begin{array}{l}-0.113 \\
(0.189)\end{array}$ \\
\hline Cost to income ratio & $\begin{array}{c}-0.021 \cdots \\
(0.001)\end{array}$ & $-0.021 \cdots$ & $\begin{array}{c}-0.019^{\circ} \\
(0.001)\end{array}$ & $\begin{array}{c}-0.011 \cdots \\
(0.002)\end{array}$ \\
\hline Size & $\begin{array}{c}-0.503^{\cdots} \\
(0.093)\end{array}$ & $\begin{array}{c}-0.503^{\cdots} \\
(0.093)\end{array}$ & $\begin{array}{c}-0.670^{*} \\
(0.106)\end{array}$ & $\begin{array}{l}-0.565 \\
(0.362)\end{array}$ \\
\hline Non interest income & $\begin{array}{l}0.158 * \\
(0.078)\end{array}$ & $\begin{array}{l}0.158^{*} \\
(0.078)\end{array}$ & $\begin{array}{c}0.016 \\
(0.087)\end{array}$ & $\begin{array}{c}0.485 \\
(0.318)\end{array}$ \\
\hline Interest incomes & $\frac{0.358 * \cdots}{(0.121)}$ & $\underset{(0.121)}{0.358^{*}}$ & $\begin{array}{l}0.245^{\circ} \\
(0.144)\end{array}$ & $\begin{array}{c}1.129 \cdots \\
(0.430)\end{array}$ \\
\hline Interest expenses & $\begin{array}{c}-0.297 \cdots \\
(0.057)\end{array}$ & $\begin{array}{c}-0.297 \\
(0.057)\end{array}$ & $\begin{array}{c}-0.203^{\cdots} \\
(0.066)\end{array}$ & $\begin{array}{c}-0.520 \cdots \\
(0.205)\end{array}$ \\
\hline НHI & & $\begin{array}{c}40.379 \\
(71.225)\end{array}$ & $\begin{array}{c}2.720 \\
(64.314)\end{array}$ & $\begin{array}{r}-48.989 \\
(62.432)\end{array}$ \\
\hline Sector Size & & $\begin{array}{l}-0.707 \\
(4.081)\end{array}$ & $\begin{array}{c}0.153 \\
(3.632)\end{array}$ & $\begin{array}{c}0.858 \\
(0.978)\end{array}$ \\
\hline Inflation & & $\begin{array}{c}0.865 \\
(0.530)\end{array}$ & $\begin{array}{l}0.581 \cdots \\
(0.284)\end{array}$ & $\begin{array}{l}-0.615^{\circ} \\
(0.334)\end{array}$ \\
\hline Growth GDP & & $\begin{array}{l}-0.016 \\
(0.063)\end{array}$ & $\begin{array}{l}-0.006 \\
(0.056)\end{array}$ & $\begin{array}{l}-0.005 \\
(0.466)\end{array}$ \\
\hline GDP per Capita & & $\begin{array}{l}-1,306 \\
(3.580)\end{array}$ & $\begin{array}{l}-0.666 \\
(3.189)\end{array}$ & $\begin{array}{l}-0.396 \\
(3.120)\end{array}$ \\
\hline MRO & & $\begin{array}{c}0.432 \\
(0.873)\end{array}$ & $\begin{array}{c}0.485 \\
(0.476)\end{array}$ & $\begin{array}{l}0.308 \\
(0.606)\end{array}$ \\
\hline 10-years Bonds & & $\begin{array}{l}-0.245^{\circ} \\
(0.143)\end{array}$ & $\begin{array}{l}-0.118^{*} \\
(0.067)\end{array}$ & $\begin{array}{l}-0.158 \\
(0.299)\end{array}$ \\
\hline Constant & $\begin{array}{c}1.421 \cdots \cdots \\
(0.424)\end{array}$ & $\begin{array}{c}2.940 \\
(21.487)\end{array}$ & $\begin{array}{c}9.987 \\
(19.129)\end{array}$ & $\begin{array}{l}12.057 \\
(14.708)\end{array}$ \\
\hline Observations & 608 & 608 & 608 & 562 \\
\hline $\begin{array}{l}\text { R-squared } \\
\text { Number of bankname1 }\end{array}$ & 0.540 & 0.540 & 115 & 115 \\
\hline
\end{tabular}

Italian banks should have higher management of their interest expenses to decrease their vulnerability. On the other hand, the interest income still shows positive results but at a weak level of significance (10\%).

For the measure of concentration, where we use the HHI, the coefficient is now nonsignificant, which suggests the absence of a relationship between concentration and the welfare of the banking industry. Since 2008, we can observe an increase in concentration in the Italian banking industry, certainly owed to the fusion or purchase from one bank to the other but also by the bankruptcies. Despite this, the concentration is still at a low level with a maximum value of 0.0452 during our period analysed.

In our whole sample, as explained in the previous section, the size of the banking industry has a negative relationship with financial soundness. In the analysis of the Italian banks, this factor becomes positive but non-significant. We can then state that the size of the banking sector in Italy does not affect its soundness. One interesting result is regarding inflation. Opposite to the first analysis and in agreement with our hypothesis, we find here a positive relationship between inflation and financial soundness, which suggests that inflation is good support for banks.

The interest rate on the ten-year bonds in Italy have a negative coefficient. This means if the risk of the country increases, which is reflected in its interest rate on 10-year bonds, the financial soundness of the banking system will decrease and vice versa. 
Notice that this coefficient shows a weak significant level of $10 \%$. Regarding the other macroeconomic factors of the Italian banks, none of them yields significant results. We can state that the recuperation of the Italian banking system is owed to managerial factors. The macroeconomic factors and the banking industry factors, apart from the inflation and the interest rate on bonds, did not seem to have had any influence on the resurrection. With respect to the size of the bank, GDP growth rate, GDP per capita, loan loss provision, equity, the cost to income ratio, asset structure, revenue diversification and the MRO, the results obtained are similar in terms of sign and significance to the regression of the whole sample.

The GMM estimator corroborates most of the findings for Italy. However, there still are some differences as to the size of the banks, with the coefficient now becoming non-significant. The effect of the interest income becomes five times stronger and with a higher level of significance. For the macroeconomic factors, the only one which is still marginally significant at a level of $10 \%$ is inflation.

4.5.2 Main Results for Portugal: We present the main result for Portugal in Table 4. The Hausman test suggests using a Random Effects model. Unlike the previous regressions, results regarding Portugal are significantly poor. This can be due to a lack of variation or misspecification of the model for this country, coupled with a small sample size of only 57 observations, the lowest of any country. Moreover, the Sargan test suggests an over-identified model.

The cost to income ratio shows, as expected, a negative and significant relationship with our proxy of financial soundness. This result agrees with the findings in Italy and the whole sample analysis. The loss loan provision, as suggested before, highlights that a higher amount of provision deteriorates the strengthening of the Portuguese banking system. Regarding the customer deposits, we find, as in Italy, a negative relationship, which is surprising, knowing that this is a stable and cheap way of financing. The other factors in the analysis of the Portuguese banks are not significant.

4.5.3 Main Results for Spain: Results for Spain are presented in Table 5. With a sample of 174 observations, the results are closer to those obtained in Italy than Portugal. The amelioration in the banking system in this country does not seem to be supported by the customers' deposits. This factor becomes negative in the case of the Spanish banks and highly significant. The financial structure of these banks is thus not based on this stable financing. In agreement with our hypothesis, which hypothesised an ambiguous effect, we can state that the Spanish banking system was in a "depositwar" context in order to lure deposits. Banks decided to increase the remuneration of the deposits which have to weaken the financial soundness. The cost of income ratio provides us with the same nexus as previously, which is negative, but with a low degree of significance, established at $10 \%$. The measure of the concentration, through the HHI, gives us the surprising result. We find a positive and significant relation with the $\mathrm{z}$-score. Notice that, it is surprising because the value of the coefficient is $1,165.5$. 
Table 4. Determinants of the Banks Resurrection in Portugal

\begin{tabular}{|c|c|c|c|c|}
\hline VARIABLES & $\begin{array}{c}\text { (1) } \\
z \text {-score }\end{array}$ & $\begin{array}{c}\text { (2) } \\
z \text {-score }\end{array}$ & $\begin{array}{c}\text { (8) } \\
z \text {-score }\end{array}$ & $\begin{array}{c}\text { (9) } \\
z \text {-score }\end{array}$ \\
\hline$Z$-score $\{t-1\}$ & & & & $\begin{array}{c}0.869^{* \cdots} \\
(0.345)\end{array}$ \\
\hline Total Loans & $\begin{array}{c}-0.034 \\
(0.158)\end{array}$ & $\begin{array}{l}-0.034 \\
(0.158)\end{array}$ & $\begin{array}{l}-0.151 \\
(0.166)\end{array}$ & $\begin{array}{l}-0.156 \\
(0.152)\end{array}$ \\
\hline Loan loss provision & $\begin{array}{c}-0.204 \cdots \\
(0.072)\end{array}$ & $\begin{array}{c}-0.204 \cdots \\
(0.072)\end{array}$ & $\begin{array}{c}-0.211 \cdots \\
(0.070)\end{array}$ & $\begin{array}{c}-0.175^{* 0} \\
(0.073)\end{array}$ \\
\hline Equity & $\begin{array}{l}-0.022 \\
(0.228)\end{array}$ & $\begin{array}{l}-0.022 \\
(0.228)\end{array}$ & $\begin{array}{c}0.047 \\
(0.234)\end{array}$ & $\begin{array}{l}-0.009 \\
(0.222)\end{array}$ \\
\hline Customer deposits & $\begin{array}{l}-0.118^{*} \\
(0.064)\end{array}$ & $\begin{array}{l}-0.118^{*} \\
(0.064)\end{array}$ & $\begin{array}{c}-0.133^{*} \\
(0.073)\end{array}$ & $\begin{array}{l}-0.108 \\
(0.074)\end{array}$ \\
\hline Cost to income ratio & $\begin{array}{c}-0.015^{\cdots} \\
(0.002)\end{array}$ & $\begin{array}{c}-0.015^{*+0} \\
(0.002)\end{array}$ & $\begin{array}{c}-0.013^{*+} \\
(0.002)\end{array}$ & $\begin{array}{c}-0.012^{\cdots} \\
(0.002)\end{array}$ \\
\hline Size & $\begin{array}{c}-0.031 \\
(0.316)\end{array}$ & $\begin{array}{c}-0.031 \\
(0.316)\end{array}$ & $\begin{array}{l}-0.160 \\
(0.340)\end{array}$ & $\begin{array}{c}-0.288 \\
(0.333)\end{array}$ \\
\hline Non interest income & $\begin{array}{c}0.239 \\
(0.229)\end{array}$ & $\begin{array}{c}0.239 \\
(0.229)\end{array}$ & $\begin{array}{c}0.139 \\
(0.248)\end{array}$ & $\begin{array}{l}-0.098 \\
(0.255)\end{array}$ \\
\hline Interest incomes & $\begin{array}{c}0.196 \\
(0.281)\end{array}$ & $\begin{array}{c}0.196 \\
(0.281)\end{array}$ & $\begin{array}{c}0.229 \\
(0.302)\end{array}$ & $\begin{array}{c}0.275 \\
(0.277)\end{array}$ \\
\hline Interest expenses & $\begin{array}{r}-0.084 \\
(0.316)\end{array}$ & $\begin{array}{l}-0.084 \\
(0.316)\end{array}$ & $\begin{array}{l}-0.043 \\
(0.331)\end{array}$ & $\begin{array}{l}-0.169 \\
(0.291)\end{array}$ \\
\hline НнІ & & $\begin{array}{c}113.328 \\
(176.692)\end{array}$ & $\begin{array}{c}84.072 \\
(159.631)\end{array}$ & $\begin{array}{c}67.226 \\
(44.871)\end{array}$ \\
\hline Sector Size & & $\begin{array}{l}-5.232 \\
(9.202)\end{array}$ & $\begin{array}{l}-3.017 \\
(8.373)\end{array}$ & $\begin{array}{l}-2.144 \\
(7.472)\end{array}$ \\
\hline Inflation & & $\begin{array}{l}-0.038 \\
(0.133)\end{array}$ & $\begin{array}{l}-0.043 \\
(0.123)\end{array}$ & $\begin{array}{l}-0.056 \\
(0.145)\end{array}$ \\
\hline Growth GDP & & $\begin{array}{c}-0.162 \\
(0.281)\end{array}$ & $\begin{array}{l}-0.077 \\
(0.255)\end{array}$ & \\
\hline GDP per Capita & & $\begin{array}{l}-3.353 \\
(3.495)\end{array}$ & $\begin{array}{l}-2.368 \\
(3.323)\end{array}$ & \\
\hline MRO & & $\begin{array}{c}0,079 \\
(0.105)\end{array}$ & $\begin{array}{c}0,038 \\
(0.106)\end{array}$ & $\begin{array}{c}0.067 \\
(0.339)\end{array}$ \\
\hline 10 -years Bonds & & $\begin{array}{l}-0.032 \\
(0.225)\end{array}$ & $\begin{array}{l}-0.162 \\
(0.260)\end{array}$ & $\begin{array}{l}-0.558 \\
(0.637)\end{array}$ \\
\hline Constant & $\begin{array}{c}0.598 \\
(1.332)\end{array}$ & $\begin{array}{c}-47.496 \\
(111.153)\end{array}$ & $\begin{array}{l}-25.167 \\
(99.217)\end{array}$ & $\begin{array}{l}-6.629 \\
(5.241)\end{array}$ \\
\hline $\begin{array}{l}\text { Observations } \\
\text { R-squared }\end{array}$ & $\begin{array}{l}57 \\
0.817\end{array}$ & $\begin{array}{c}57 \\
0.817\end{array}$ & $\begin{array}{c}57 \\
0,756\end{array}$ & 45 \\
\hline Number of bankname 1 & & & 16 & 16 \\
\hline
\end{tabular}

The coefficient lets us circumspect and we are prudent regarding the analysis of these finding. Nevertheless, the Spanish banking industry is a bit different from the other countries. It is composed of a high number of savings banks - the so-called cajas created in the 19th century as non-profit entities (Trujillo-Ponce, 2013). In fact, Spain has the largest number of bank branches per capita in Europe. Nowadays, these cajas operate as traditional commercial banks, but act as local banks and focus their activity on local activities. During the 2000 decade, they started to operate out of their regional area, going to foreign markets. In doing this, they faced high losses, which highlight the considerable risk taken by these banks. Most of them have been absorbed by other banking groups, reducing their number considerably during an important restructuring process. Therefore, it is highly probable that this process enhanced the overall financial soundness, even though this coefficient seems exaggerated in comparison with the analysis of other countries. The size of the sector is in complete opposition with what we have found previously. In the case of the Spanish banks, it is seen that a wide banking industry provides an amelioration of the banking strength. The coefficient is positive, high and significant and as for the concentration, the coefficient seems to be high, 90.198. Contrary to the analysis of the whole sample, in the case of Spain, all the macroeconomic factors are significant. The role of inflation agrees with our hypothesis. We find a positive and significant, at the 5\% level, correlation with the financial soundness. 
Table 5. Determinants of the Banks Resurrection in Spain

\begin{tabular}{|c|c|c|c|c|}
\hline VARIABLES & $\begin{array}{c}(1) \\
z \text {-score }\end{array}$ & $\begin{array}{c}(2) \\
z \text {-score }\end{array}$ & $\begin{array}{c}(3) \\
z \text {-score }\end{array}$ & $\begin{array}{c}(4) \\
z \text {-score }\end{array}$ \\
\hline$z$-score $(t-1)$ & & & & $\begin{array}{l}0.203^{* \cdots} \\
(0.049)\end{array}$ \\
\hline Total Loans & $\begin{array}{c}-0.203^{\cdots} \cdots \\
(0.063)\end{array}$ & $\begin{array}{c}-0.203^{\cdots} \cdots \\
(0.063)\end{array}$ & $\begin{array}{c}-0.205 \cdots \\
(0.067)\end{array}$ & $\begin{array}{c}0.013 \\
(0.114)\end{array}$ \\
\hline Loan loss provision & $\begin{array}{c}-0.279 \cdots \\
(0.048)\end{array}$ & $\begin{array}{c}-0.279^{\cdots \cdots} \\
(0.048)\end{array}$ & $\begin{array}{c}-0.291 \cdots \\
(0.048)\end{array}$ & $\begin{array}{c}-0.388^{* \cdots} \\
(0.071)\end{array}$ \\
\hline Equity & $\begin{array}{l}0.293^{* \cdots} \\
(0.055)\end{array}$ & $\begin{array}{c}0.293^{* \cdots} \\
(0.055)\end{array}$ & $\begin{array}{c}0.301 \cdots \\
(0.059)\end{array}$ & $\begin{array}{c}0.274 * \cdots \\
(0.088)\end{array}$ \\
\hline Customer deposits & $\begin{array}{c}-0.150^{* \cdots} \\
(0.056)\end{array}$ & $\begin{array}{c}-0.150^{\cdots} \\
(0.056)\end{array}$ & $\begin{array}{c}-0.158^{\cdots} \\
(0.059)\end{array}$ & $\begin{array}{c}-0.360^{*}+\cdots \\
(0.099)\end{array}$ \\
\hline Cost to income ratio & $\begin{array}{c}-0.003^{*} \\
(0.002)\end{array}$ & $\begin{array}{l}-0.003^{*} \\
(0.002)\end{array}$ & $\begin{array}{l}-0.003^{*} \\
(0.002)\end{array}$ & $\begin{array}{c}-0.003^{*} \\
(0.002)\end{array}$ \\
\hline Size & $\begin{array}{c}-0.467 \cdots \\
(0.083)\end{array}$ & $\begin{array}{c}-0.467 \cdots \cdots \\
(0.083)\end{array}$ & $\begin{array}{c}-0.489^{\cdots \cdots} \\
(0.086)\end{array}$ & $\begin{array}{c}-0.651 \cdots \\
(0.141)\end{array}$ \\
\hline Non interest income & $\begin{array}{l}0.059 \\
(0.062)\end{array}$ & $\begin{array}{c}0.059 \\
(0.062)\end{array}$ & $\begin{array}{l}0.055 \\
(0.063)\end{array}$ & $\begin{array}{l}-0.071 \\
(0.130)\end{array}$ \\
\hline Interest incomes & $\begin{array}{c}0.563^{* \cdots} \\
(0.136)\end{array}$ & $\begin{array}{c}0.563^{* \cdots} \\
(0.136)\end{array}$ & $\begin{array}{l}0.558 \cdots \cdots \\
(0.145)\end{array}$ & $\begin{array}{l}0.724 \cdots \cdots \\
(0.245)\end{array}$ \\
\hline Interest expenses & $\begin{array}{l}-0.117 \\
(0.093)\end{array}$ & $\begin{array}{l}-0.117 \\
(0.093)\end{array}$ & $\begin{array}{l}-0.111 \\
(0.097)\end{array}$ & $\begin{array}{l}-0.381 \cdots \\
(0.153)\end{array}$ \\
\hline НHI & & $\begin{array}{c}1,151.127 \cdots \\
(520.786)\end{array}$ & $\begin{array}{c}1,165.484 * \cdots \\
(510.179)\end{array}$ & \\
\hline Sector Size & & $\begin{array}{l}89.005 * 7 \\
(41.417)\end{array}$ & $\begin{array}{l}90.198^{\circ} \\
(40.530)\end{array}$ & $\begin{array}{c}-6.118^{\cdots \cdots} \\
(1.470)\end{array}$ \\
\hline Inflation & & $\begin{array}{c}12.924 \cdots \\
(5.552)\end{array}$ & $\begin{array}{c}13.068 * \\
(5.437)\end{array}$ & $\begin{array}{c}0.210 \\
(0.238)\end{array}$ \\
\hline Growth GDP & & $\begin{array}{c}-0.922 \cdots \\
(0.436)\end{array}$ & $\begin{array}{l}-0.935 \cdots \\
(0.428)\end{array}$ & $\begin{array}{c}0.476 * \cdots) \\
(0.130)\end{array}$ \\
\hline GDP per Capita & & $\begin{array}{c}166.581 * \\
(74.052)\end{array}$ & $\begin{array}{c}168.612 * \\
(72.529)\end{array}$ & \\
\hline MRO & & $\begin{array}{c}0.418 * \cdots \\
(0.136)\end{array}$ & $\begin{array}{l}1.562^{*} \\
(0.738)\end{array}$ & $\begin{array}{c}0.059 \\
(0.048)\end{array}$ \\
\hline 10-years Bonds & & $\begin{array}{l}-0.954 \cdots \\
(0.421)\end{array}$ & $\begin{array}{l}-0.922 \cdots \\
(0.392)\end{array}$ & $\begin{array}{c}-0.935 \cdots \\
(0.428)\end{array}$ \\
\hline Constant & $\begin{array}{l}-0.811 \cdots \\
(0.399)\end{array}$ & $\begin{array}{l}-647.387 * \\
(264.820)\end{array}$ & $\begin{array}{l}-653.889 * \cdots \\
(259.815)\end{array}$ & $\begin{array}{c}-69.399 \cdots \\
(17.805)\end{array}$ \\
\hline $\begin{array}{l}\text { Observations } \\
\text { R-squared }\end{array}$ & $\begin{array}{c}174 \\
0.436\end{array}$ & $\begin{array}{c}174 \\
0.436\end{array}$ & 174 & 136 \\
\hline Number of bankname 1 & & & 49 & 47 \\
\hline
\end{tabular}

We can interpret that Spanish banks have good anticipation of the inflation and then can set their interest rates on loans and deposits in agreement with that. Notice that the value of the coefficient is 13.07 which seems to be higher with respect to the findings in the previous literature, by Căpraru and Ihnatov (2014) and Uhde and Heimeshoff (2009). The growth of the real GDP penalizes the financial soundness in Spain, where we find a negative and significant coefficient. Again, this result looks surprising for us where we expected that an increase of the GDP would lead to higher financial soundness since banks would be evolving in a better environment.

Nevertheless, the measure of the GDP per capita, which seems to us a better measure of wealth, shows a positive relationship between the factors and the financial soundness. This finding suggests that banks evolving in a more developed environment exhibit higher financial soundness. Notice that the value of this coefficient is very high, 168.112, which is surprising. The other factors as the total of loans, the assets quality, the capitalization, the size, the revenue diversification, the interest management, the MRO and the 10-years bonds yields present similar characteristics to the findings of the whole sample. In the analysis of Spain, the GMM estimator provides us with interesting results.

Firstly, the coefficient regarding the loans becomes non-significant, which mitigate the fact that loans have been detrimental for the financial soundness. For the interest 
expenses, the coefficient is still negative but becomes significant at a level of 5\%, which agrees with our hypothesis. Previously, we mentioned how both the coefficient of the measure of the concentration, the HHI, and of the GDP per capita had a surprisingly high value. The GMM estimator eliminated these two factors of the analysis. This can be because the Sargan test specified an over-identified model. We can then note that these factors were biasing the regression.

\subsection{Analysis of the regression of the four countries that had benefited from assistance programmes}

This part of the study focusses on the four countries, Ireland, Greece, Portugal and Spain that have benefited from financial assistance programmes. Results are presented in Table 6. In line with the banking literature, we run the same regression as in the analysis of the whole sample including the natural logarithm of the amounts received from the programmes for each country and per year. These programmes are divided into different loans tranches and since we use yearly data, we do the sum of the loans per year. We consider the assistance programmes from the European Financial Stability Facility (EFSF) and the International Monetary Fund (IMF). The results regarding the bank-specific factors are almost identical to those obtained previously. Nevertheless, here are some differences in the analysis of the whole sample.

We notice that, contrary to the analysis of the whole sample, customer deposits have a negative effect on financial soundness, which again, is somewhat surprising. In the analysis of these four countries, it seems that the customer deposits have been detrimental for financial soundness. This can be since banks were operating in the context of a "deposit-war" which decreased their profitability. The factors regarding the banking industry also give us different results. The size of the sector still shows a negative sign but becomes non-significant. The measure of concentration, which had a positive and strong significant coefficient in the regression of the whole sample, became non-significant in the analyses of these countries. The banking sector factors don't seem to have played an important role in the restructuring of the banking systems of these countries.

The results about the macroeconomic factors are also quite different. Inflation still has a negative coefficient, but the significance level has increased to $1 \%$. We can then assume that inflation as for the whole sample is not fully anticipated. Moreover, the context of very low inflation could have been detrimental for the banks in preventing a good set of interest rates. Contrary to our first analysis, the rate of growth of the real GDP is statistically significant at the 5\% level, in agreement with our hypothesis. For these four countries during the period studied, we can observe an improvement in growth after the important drop following the crisis of 2008 (see appendix 2 Figure). Economic growth should have helped banks improve their financial soundness, in line with ameliorating economic conditions. 
Table 6. Determinants of Bank's Resurrection in Countries Provide with Financial Assistance

\begin{tabular}{|c|c|c|c|c|}
\hline VARIABLES & $\begin{array}{c}\text { (1) } \\
\text { z-score }\end{array}$ & $\begin{array}{c}\text { (2) } \\
z \text {-score }\end{array}$ & $\begin{array}{c}\text { (3) } \\
\text { z-score }\end{array}$ & $\begin{array}{c}\text { (9) } \\
\text { z-score }\end{array}$ \\
\hline z-score $(t-1)$ & & & & $\begin{array}{l}0,418^{*} \\
(0.204)\end{array}$ \\
\hline Total Loans & $\begin{array}{c}-0.224 \cdots \\
(0.055)\end{array}$ & $\begin{array}{c}-0.209^{\prime} \\
(0.054)\end{array}$ & $\begin{array}{c}-0.263 \cdots \\
(0.067)\end{array}$ & $\begin{array}{c}-0.359^{\cdots} \\
(0.131)\end{array}$ \\
\hline Loan loss provision & $\begin{array}{c}-0.344 * \cdots \\
(0.036)\end{array}$ & $\begin{array}{c}0.322 \cdots \\
(0.038)\end{array}$ & $\begin{array}{c}-0.347+\cdots \\
(0.040)\end{array}$ & $\begin{array}{c}-0.421 \cdots \\
(0.075)\end{array}$ \\
\hline Equity & $\begin{array}{c}0.259 \cdots \\
(0.053)\end{array}$ & $\begin{array}{c}0.239 \cdots \\
(0.053)\end{array}$ & $\begin{array}{c}0.298 \cdots \\
(0.065)\end{array}$ & $\begin{array}{c}0.500 \cdots \\
(0.101)\end{array}$ \\
\hline Customer deposits & $\begin{array}{c}-0.110 * \cdots \\
(0.040)\end{array}$ & $\begin{array}{c}0.1100 . \\
(0.040)\end{array}$ & $\begin{array}{c}-0.128 \times \\
(0.051)\end{array}$ & $\begin{array}{l}-0.037 \\
(0.076)\end{array}$ \\
\hline cost to income ratio & $\begin{array}{c}-0.006+\cdots \\
(0.001)\end{array}$ & $\underset{(0.001)}{-0.006 \cdots}$ & $\begin{array}{c}-0.005+\cdots \\
(0.001)\end{array}$ & $\begin{array}{r}-0.009 \cdots \\
(0.002)\end{array}$ \\
\hline Size & $\begin{array}{c}-0.443 \cdots \\
(0.074)\end{array}$ & $\begin{array}{c}-0.435 \cdots \\
(0.074)\end{array}$ & $\begin{array}{c}-0.513 \cdots+ \\
(0.037)\end{array}$ & $\begin{array}{c}-0.739 \cdots \\
(0.162)\end{array}$ \\
\hline Non interest income & $\begin{array}{l}0.120 * \cdots \\
\text { (0.053) }\end{array}$ & $\begin{array}{l}0.094^{*} \\
(0.054)\end{array}$ & $\begin{array}{c}0.092 \\
(0.062)\end{array}$ & $\begin{array}{l}0.128 \\
(0.111)\end{array}$ \\
\hline Interest incomes & $\begin{array}{c}0.307 \cdots \\
(0.076)\end{array}$ & $\begin{array}{l}0.229^{\prime} \\
(0.091)\end{array}$ & $\begin{array}{c}0.339^{2} \cdots \\
(0.107)\end{array}$ & $\begin{array}{c}0.534 \cdots \\
(0.142)\end{array}$ \\
\hline Interest expenses & $\begin{array}{l}-0.029 \\
(0.044)\end{array}$ & $\begin{array}{c}0.020 \\
(0.067)\end{array}$ & $\begin{array}{c}0.026 \\
(0.067)\end{array}$ & $\begin{array}{c}0.126 \\
(0.083)\end{array}$ \\
\hline нні & & $\begin{array}{l}-0.559 \\
(2.978)\end{array}$ & $\begin{array}{l}-0.147 \\
(2.933)\end{array}$ & $\begin{array}{l}-0.227 \\
(0.209)\end{array}$ \\
\hline sector size & & $0.922 \%$ & $\begin{array}{l}-0.184 \\
(0.337)\end{array}$ & $\begin{array}{l}-0.330 \\
(0.452)\end{array}$ \\
\hline Inflation & & $\begin{array}{c}-0.179 * \\
(0.070)\end{array}$ & $\begin{array}{c}-0.131 \cdots \\
(0.061)\end{array}$ & $\begin{array}{r}-0.110^{*} \\
(0.040)\end{array}$ \\
\hline Growth GDP & & $\begin{array}{l}0.079 * \\
(0.031)\end{array}$ & $\begin{array}{l}0.194 \% \\
\text { (0.086) }\end{array}$ & $\begin{array}{l}-0.023 \\
(0.034)\end{array}$ \\
\hline GDP per Capita & & $\begin{array}{c}-1.552 \cdots \\
(0.474)\end{array}$ & $\begin{array}{l}-0.413 \\
(0.394)\end{array}$ & $\begin{array}{c}0.405 \\
(0.470)\end{array}$ \\
\hline MRO & & $\begin{array}{l}-0.130 \\
(0.238)\end{array}$ & $\begin{array}{l}-0.227 \\
(0.209)\end{array}$ & $\begin{array}{l}-0.107 \\
(0.198)\end{array}$ \\
\hline 10-years Bonds & & $\begin{array}{l}0.483 \\
(0.321)\end{array}$ & $\begin{array}{l}0.211 \\
(0.300)\end{array}$ & $\begin{array}{c}0.539 \\
(0.539)\end{array}$ \\
\hline Financial assistance & & $\begin{array}{l}0.016 \cdots \\
(0.008)\end{array}$ & $\begin{array}{l}0.294 * \cdots \\
(0.114)\end{array}$ & $\begin{array}{l}0.229 \cdots \\
(0.096)\end{array}$ \\
\hline Constant & $\begin{array}{l}-0.530^{*} \\
(0.319)\end{array}$ & $\begin{array}{c}27.641 \cdots \\
(9.648)\end{array}$ & $\begin{array}{c}1.728 \\
(6.896)\end{array}$ & $\begin{array}{l}-8.583 \\
(9.458)\end{array}$ \\
\hline $\begin{array}{l}\text { Observations } \\
\text { R-squared } \\
\text { Number of bankname1 }\end{array}$ & $\begin{array}{c}277 \\
0.462\end{array}$ & $\begin{array}{l}277 \\
0.503\end{array}$ & $\begin{array}{c}277 \\
0,493 \\
77\end{array}$ & 219 \\
\hline
\end{tabular}

$+\cdots p<0.01, \ldots p<0.05, * p<0.1$

The coefficients on interest rates, such as the MRO or the interest rates on 10-years bonds, are now not significant. Nevertheless, in this part of the study, we focused on the effect of financial assistance which provides us with an interesting result. We find that the assistance programmes have been beneficial for financial soundness. The coefficient is positive and significant at a 5\% level. This finding agrees with our expectations, as these programmes have been made to reinforce the financial situations of these countries and of their banking systems through bailouts. These programmes have been important for financial soundness and participated in the resurrection of the banking systems of these four countries. As mention above, previous literature as seen in Van der Kwaak and Van Wijnbergen (2017), explain how if the bailouts are financed by their own country it can be detrimental for the sovereign debt as well as the banking stability. In this case, since the bailouts were external to the countries then this may have contributed to their overall success.

Here, the analysis the GMM estimator reinforced our findings. Differences are observed in terms of the customer deposits, which became non-significant, and to the growth of real GDP which became non-significant. For the other variables, findings are almost identical. Moreover, the GMM estimator supports the previous findings regarding the financial assistance programmes. 


\section{Summary and conclusions}

Using panel data from balance sheet data of 200 banks from five different countries over the period between 2011 to 2016 , this paper empirically analyses the main factors behind the restructure and improvement of the banking systems of these countries after the crises of the last decade. We also look for the impact of macroeconomic factors on the financial soundness of these five countries. As a contribution to the banking literature, we include an analysis of the effect of the financial assistance programmes which have characterized this period for four countries in our sample.

Italian, Irish, Greek, Portuguese and Spanish banks have been involved in an economic depression since the 2008-09 credit crunch. Nowadays they seem to have risen somewhat from the economic slump. The managerial factors are found to have played the most important role, with our results showing that this improvement has been led by a better capitalization of banks, which increases their resistance to external shocks. We attribute this characteristic to the fact that banks are now required to submit to macro-recommendations by the Basel III as transposed in the European Capital Requirement Directives. The analysis of the financial structure highlights that banks' source of finance is based on customer deposits, which represent cheap and stable financing. Nevertheless, the study of the specific countries shows that for some of them the customer deposits could have been detrimental. We argue that this situation is owed to a "deposit-war" between banks to attract deposits as much as possible, which may have had a detrimental impact on theirprofitability. The decrease in the loans, which characterized this period seems to have had a positive impact on financial soundness, as did increased monitoring on credit. Moreover, the decrease of credit in the balance sheet also decreased the liquidity risk correlated with this factor. In agreement with that, the loan loss provision shows a negative relation which emphasizes that loan monitoring and credit underwriting are necessary.

On the other hand, some factors have been detrimental for the banks in our sample. The size of banks decreases the financial soundness, which implies that control and a limitation on banks' size by public authorities is necessary to ensure financial stability, despite the economies of scale that they can show. In agreement with the previous literature, and the previous deduction regarding credit, smaller and medium banks are more able to avoid asymmetric information, which in a high default credit context is very important. The results also show that a disproportionately large banking industry in comparison with the whole economy of a country is detrimental. The size of the banking industry and the whole economy should progress at the same rhythm. This can permit the avoidance of a bubble in for example credit. The banking industry must go along with the real economy, which is mutually beneficial for both.

Our results show that a more concentrated market helps to ensure higher financial soundness. In the five countries of our sample, we observe an increase in concentration during the period of study. This finding could be in opposition to the previous statement, which highlighted that large banks can be detrimental to the soundness of 
the economy. These two findings lead us to the conclusion that medium banks are perhaps the most efficient for banking stability, with the presence of very small or very large banks harming financial soundness. Inflation has played a negative role in the resurrection of the banking systems. This result indicates weak anticipation of inflation, which in turn was detrimental for banks. Moreover, in the context of very low inflation, (close to zero), it is more difficult for the bank to set accurate interest rates, as they should expect at one moment an increase in the inflation, which can be detrimental for them. Following these findings, the results show that the Main Refinancing Operation rate is positively correlated with financial soundness. As our period of study has been characterized by a decrease in this interest rate, it may have been detrimental for financial soundness. In this context, it is difficult for banks to set the interest rate on loans and deposits in order to increase their profitability. Notice that this low-interest rate has enabled the avoidance of illiquidity risk, allowed by cheapfinancing.

With regards to other measures of interest rate, the 10-year sovereign bonds of each country exhibit a negative relationship with financial soundness. Our findings agree with the previous literature, which leads us to believe that an enhancement in public sector finances is necessary to improve banking soundness. If the fiscal situation of the country is weak, the government cannot ensure the stability of the banking system in case of a shock.

Finally, our study reveals and confirms our hypothesis that financial assistance programmes have been beneficial to improve the stability of the banking system, which was necessary to start the resurrection. The financial assistance had a positive effect because it came from other international institutions and not directly from within each country, which were already in an economic slump. Even if we observe an improvement and a strengthening of the banking systems in these countries, caution is warranted. Although crises seem to be behind us for the moment, it is imperative to exercise vigilance in order to maintain stability improvement. Banks' managers are nowadays more cautious, but there is no guarantee that such behaviour will persist in the long run. This is why public authorities must keep a close eye on the financial situation within a country and take necessary and timely action to enforce banking regulations, in order to avoid fragility in the future.

\section{References:}

Abreu, M. and Mendes V. 2002. Commercial Bank Interest Margins and Profitability: Evidence from E.U Countries. Porto working paper series.

Athanasoglou, P.P., Brissimis, S.N. and Delis M.D. 2008. Bank-specific, industry-specific and macroeconomic determinants of bank profitability. Journal of International Financial Markets, Institutions and Money, No 18, 121-136.

Aymanns C., Caceres, C., Daniel, C. and Schumacher, L. 2016. Bank solvency and funding cost. IMF Working Paper No 16/64. 
Barros C.P., Ferreira, C. and Williams J. 2007. Analysing the determinants of performance of best and worst European banks: a mixed logit approach. Journal of Banking and Finance No 31, 2189-2203.

Beck T., Demirgüç-Kunt, A. and Levine, R. 2006. Bank concentration, competition, and crises: First results. Journal of Banking and Finance, No 30, 1581-1603.

Beckmann, R. 2007. Profitability of Western European Banking Systems: Panel Evidence on Structural and Cyclical Determinants. Discussion Paper Series No 2, Banking and Financial Studies, No 17/2007.

Ben Naceur, S. 2003. The determinants of the Tunisian banking industry profitability: Panel evidence 1980-2000. 11st Conference of the Economic Research Forum (ERF).

Berger, A. 1995. The relationship between capital and earnings in banking. Journal of Money, Credit and Banking, Vol. 27, 404-431.

Căpraru, B. and Ihnatov, I. 2014. Banks' profitability in selected central and eastern European countries. 21st Conference Economic Conference, Sibiu Romania.

Demirgüç-Kunt, A. and Huizinga, H. 1999. Determinants of commercial banks interest margins and profitability: some international evidence. The World Bank Economic Review, Vol. 13, No 2, 379-408.

Demirgüç-Kunt, A. and Huizinga, H. 2001. Financial Structure and Bank Profitability 19901997. In A. Demirgüç-Kunt and R. Levine (eds.), Financial Structure and Economic Growth: A Cross-Country Comparison of Banks, Markets, and Development, Cambridge, MA: MIT Press.

De Nicolo, G., Bartholomew, P., Zaman, J. and Zephirin, M. 2004. Bank consolidation, internalization, and conglomerization. Working Paper No. 03/158, IMF.

DeYoung, R. and Rice, T. 2003. Non-interest Income and Financial Performance at U.S. Commercial Banks. Policy Studies, Federal Reserve Bank of Chicago.

Dima, B., Dincă, M.S. and Spulbăr, C. 2014. Financial Nexus: Efficiency and soundness in banking and capital markets. Journal of International Money and Finance, No 47, 100-124.

Elsas, R., Hackethal, A. and Holzhäuser, M. 2010. The anatomy of bank diversification. Journal of Banking and Finance, No 34, 1274-1287.

European Central Bank. 2018. Eurosystem. Statistical Data.

Financial Sector Assessment Program. 2017. IMF Country Report No. 17/343.

Grima, S. (2012). The Current Financial Crisis and Derivative Misuse. Journal of Social Sciences Research, Vol. 1, No. 8, 265-276.

Grima, S., Caruana, L. 2017. The Effect of the Financial Crisis on Emerging Markets. A comparative analysis of the stock market situation before and after. European Research Studies Journal, Vol. XX, Issue 4B.

Gourinhas, P.O., Martin, P. and Messer, T. 2017. The economics of sovereign debt, bailouts and the Eurozone crisis. Working Paper in collaboration between UC Berkeley and Science Po.

Iuga, I. 2013. Analysis of the banking system's concentration degree in EU countries. Annales Universitatis Apulensis Series Oeconomica, No 15(1), 184-193.

Kibritçioğlu, A. 2002. Excessive risk-taking, Banking sector fragility, and Banking Crises. Office of Research Working Paper Number 02-0114, University of Illinois.

Lapteacru, I. 2016. On the consistency of the z-score to measure the bank risk. LAREFI Working Paper No. 2016-05.

Lapteacru, I. 2017. The z-score is dead, long live the z-score! A new way to measure bank risk. LAREFI Working Paper No. 2017-01. 
Lapteacru, I. and Nys, E. 2011. L'impact de la concurrence sur l'efficience des banques: le cas de PECO. Presses de Science Po, Vol. 62, 313-329.

Mester, L.J. 1995. A study of bank efficiency taking into account risk-preferences. Journal of Banking and Finance, No 20, 1025-1045.

Miguelez, E. 2018. Les determinants de la profitabilité des banques espagnoles. Working Papers, University of Bordeaux.

Mileva, E. 2007. Using Arellano - Bond Dynamic Panel GMM Estimator in Stata. Economics Department Fordham University.

Molyneux, P. and Thornton, J. 1992. Determinants of European bank profitability 19861989: A note. Journal of Banking and Finance, Vol. 16.

Morsink, J. and Gerson, P. 2017. Financial System Stability Assessment on Spain. IMF country report No. 17/321.

Özen, E., Vurur S.N. and Grima, S. 2018. Investigation of Causality Between Interest Rate and Deposit Investor's Behaviour. Broad Research in Artificial Intelligence and Neuroscience Journal (BRAIN), Vol. 9, Issue 4.

Petria, N., Căpraru, B. and I. Ihnatov, I. 2013. Determinants of banks' profitability: Evidence from EU 27 banking systems. 7th International Conference on Globalization and Higher Education in Economics and Business Administration, Iaşi Romania.

Roman, A. and Şargu, A.C. 2013. Analysing the financial soundness of the commercial banks in Romania: An approach based on the Camels Framework. International Economic Conference of Sibiu 2013 Post Crisis Economy: Challenges and Opportunities.

Rouabah, A. 2006. La sensibilité de l'activité bancaire aux chocs macro-économiques: une analyse de panel sur des données de banques luxembourgeoises 1994-2005.

Luxembourg Central Bank, Cahier d'études, No 26, May.

Ruiz, J.R., Stupariu, P. and Vilariño, A. 2016. The crisis of Spanish savings banks. Cambridge Journal of Economics, Vol 40, issue 6.

Salha, O.B., Bouazizi, T. and Aloui, C. 2008. Libéralisation financière, crises bancaires et croissance économique: Cas des pays du sud de la Méditerranée. International Colloquium Ouverture et Emergence en Méditerranée organised by the UNECA.

Serrano, S.C. 2013. La reestructuracion del sistema bancario español tras la crisis y la solvencia de las entidades financieras. Consecuencias para las cajas de ahorros. Spanish Accounting Review, No 16, 136-146.

Sigmund, M., Gunter, U. and Krenn, G. 2017. How do macroeconomics and bank-specific variables influence profitability in the Austrian banking sector? Evidence from a panel vector autoregression analysis. Review of Banking, Finance and Monetary Economics, Economic Notes, Vol. 46, No. 3.

Thalassinos, I.E., Stamatopoulos, D.T. and Thalassinos, E.P. 2015. The European Sovereign Debt Crisis and the Role of Credit Swaps. Chapter book in The WSPC Handbook of Futures Markets (eds) W. T. Ziemba and A.G. Malliaris, in memory of Late Milton Miller (Nobel 1990) World Scientific Handbook in Financial Economic Series Vol. 5, Chapter 20, pp. 605-639, ISBN: 978-981-4566-91-9, (doi: 10.1142/9789814566926_0020).

Thalassinos, I.E., Hanias, P.M. and Curtis, G.P. 2012. Time series prediction with neural networks for the Athens Stock Exchange indicator. European Research Studies Journal, 15(2), 23-31.

Trujillo-Ponce, A. 2013. What determines the profitability of banks? Evidence from Spain. Accounting and Finance, No 53, 561-586. 
Uhde, A. and Heimeshoff, U. 2009. Consolidation in banking and financial stability in Europe: Empirical evidence. Journal of Banking and Finance, No 33, 1299-1311.

Van der Kwaak, C. and Van Wijnbergen, S. 2017. Sovereign dept and bank fragility in Spain.

Review of World Economics, Vol 153, Issue 3.

World Bank Database. 2018. https://data.worldbank.org/.

\section{Appendices:}

Appendix 1: Total Loans for Households (Right) and Corporates (Left) for each country: Source European Central Bank, 2018
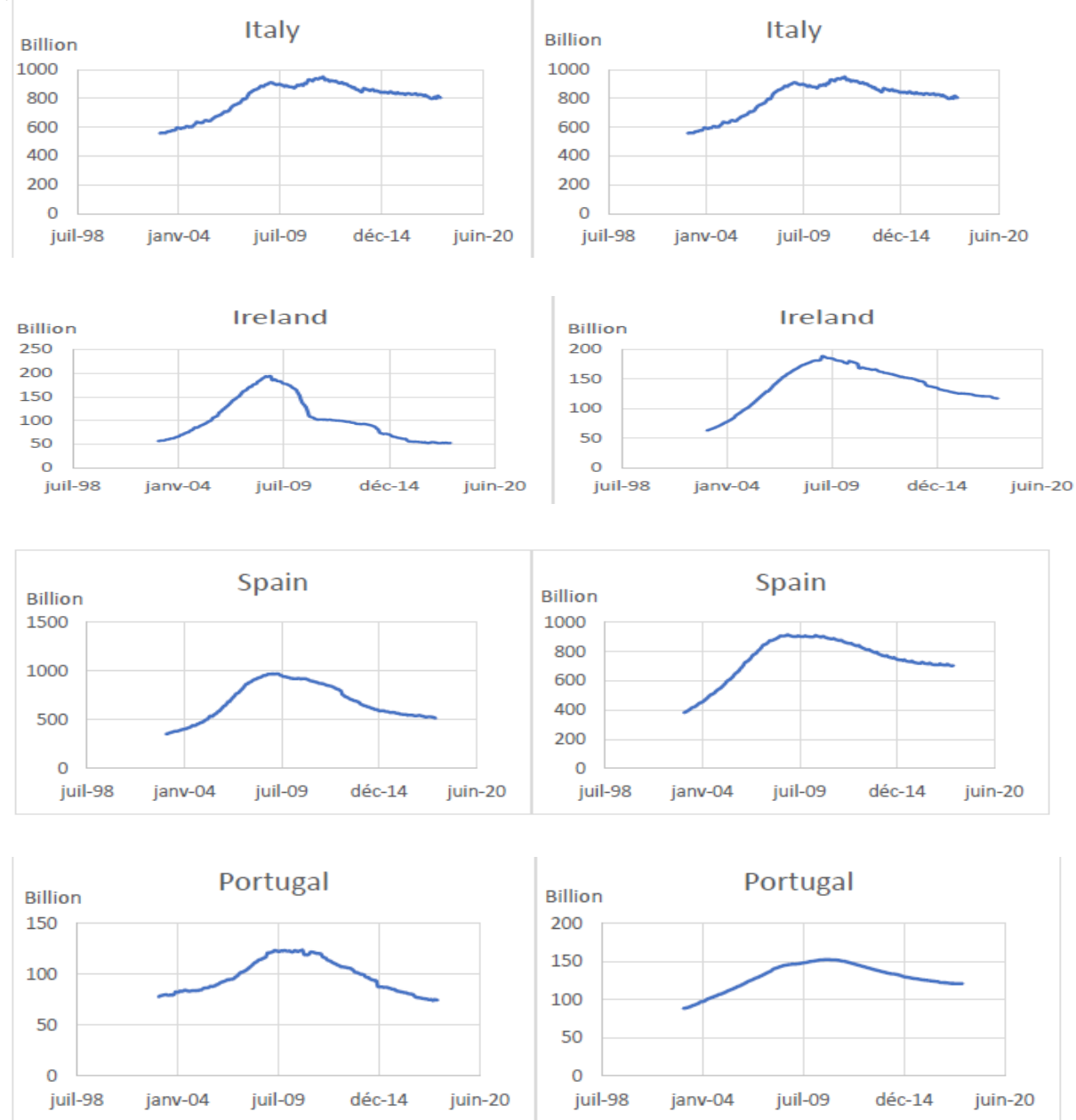

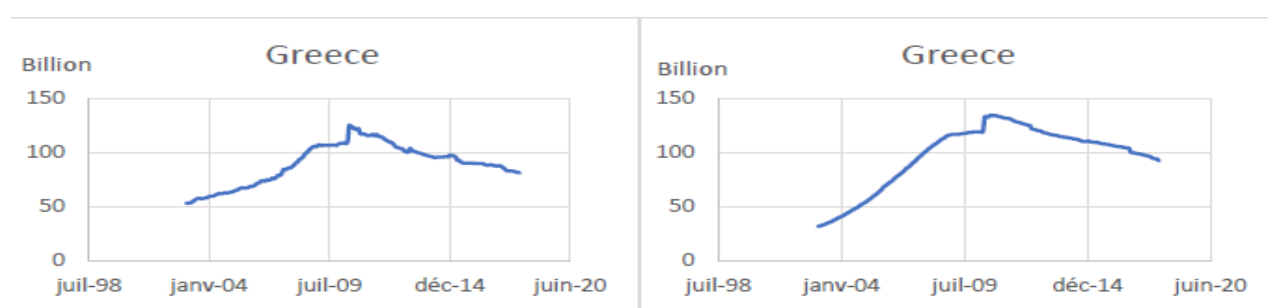

Appendix 2: Banks Non-Performing Loans to Total Gross Loans - Source: World Bank Database, 2018

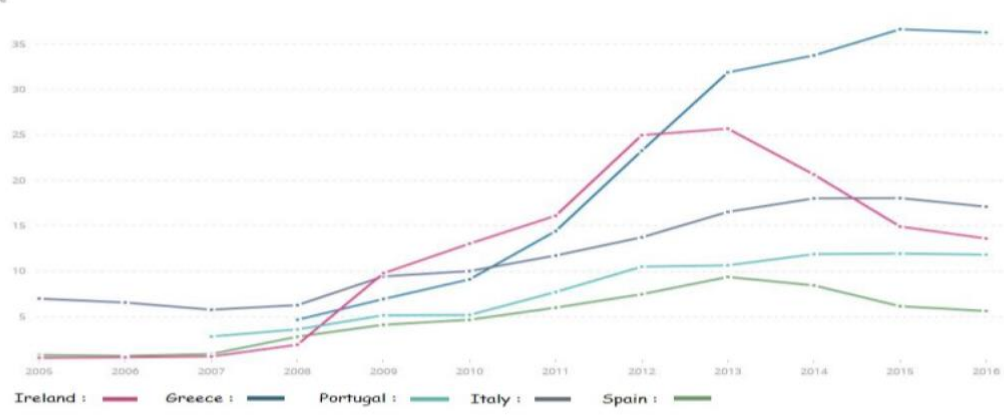

Appendix 3: Rate of the main refinancing operation of the European Central Bank

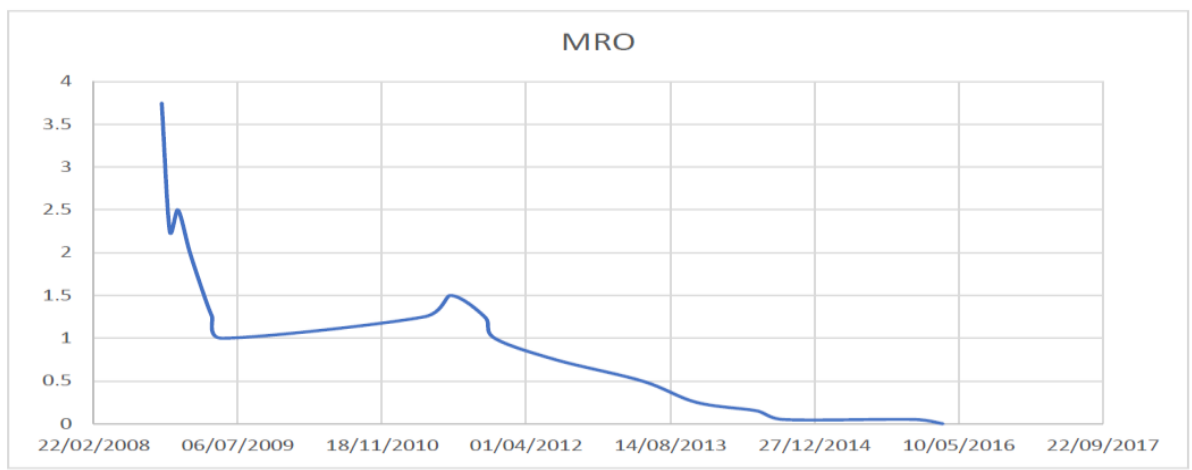

Source: European Central Bank, 2018.

Appendix 4: The Interest rate on a 10-year bond for each currency. (Eikon), 2018

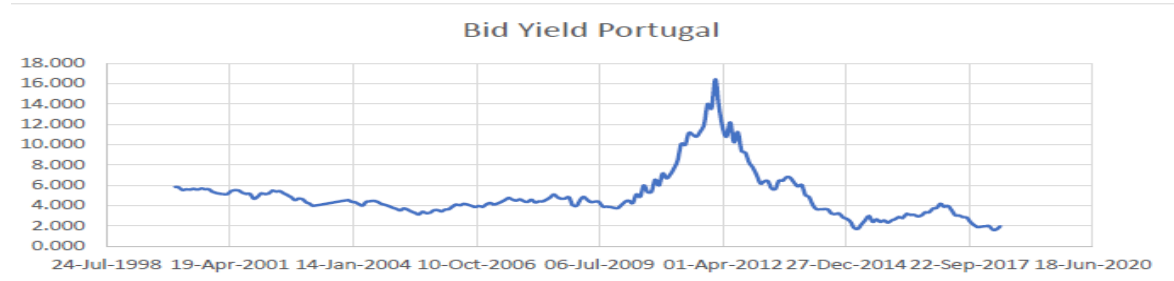

\section{Source: DataStream}



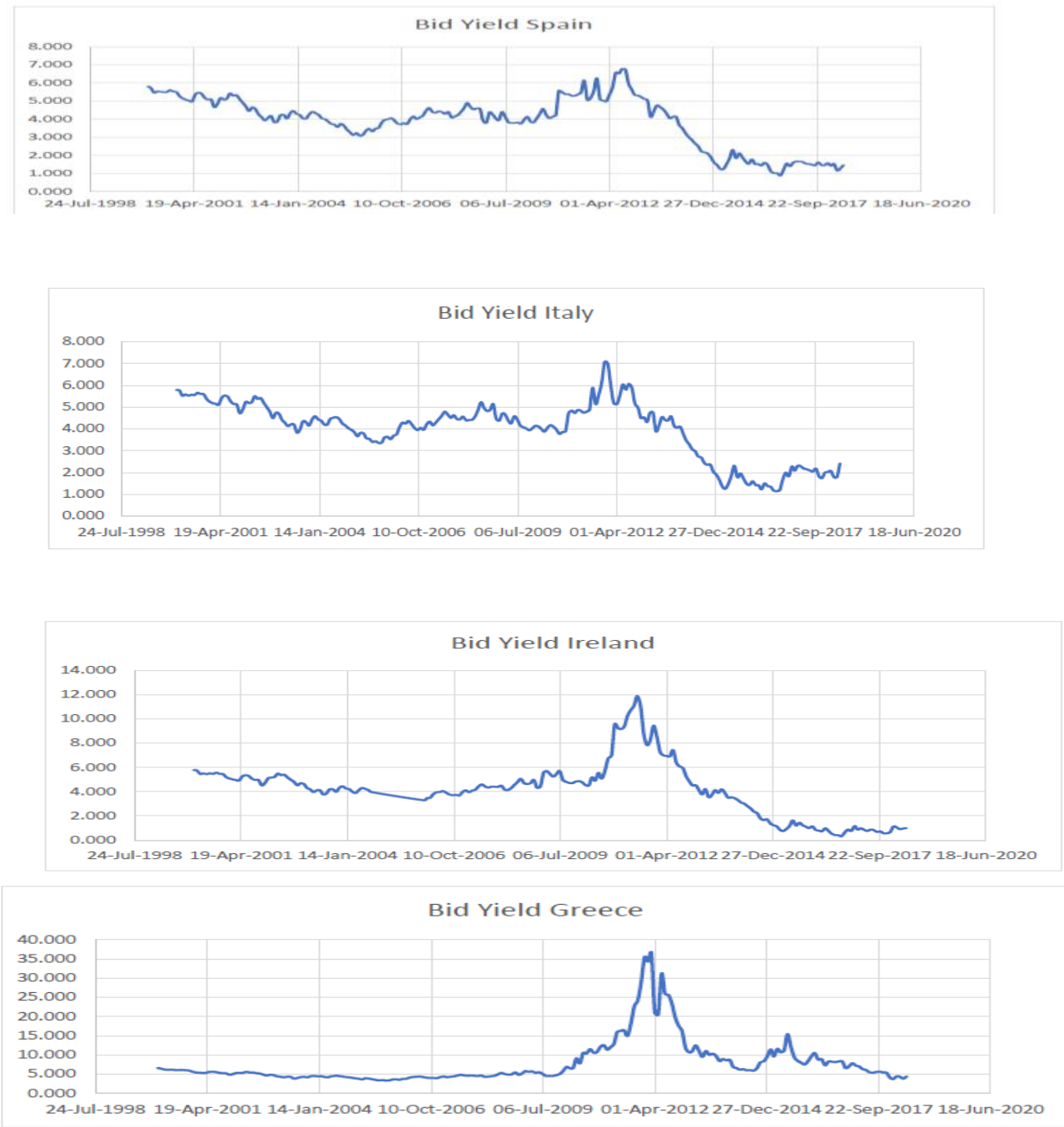

Appendix 5: Banks non-performing loans to total gross loans

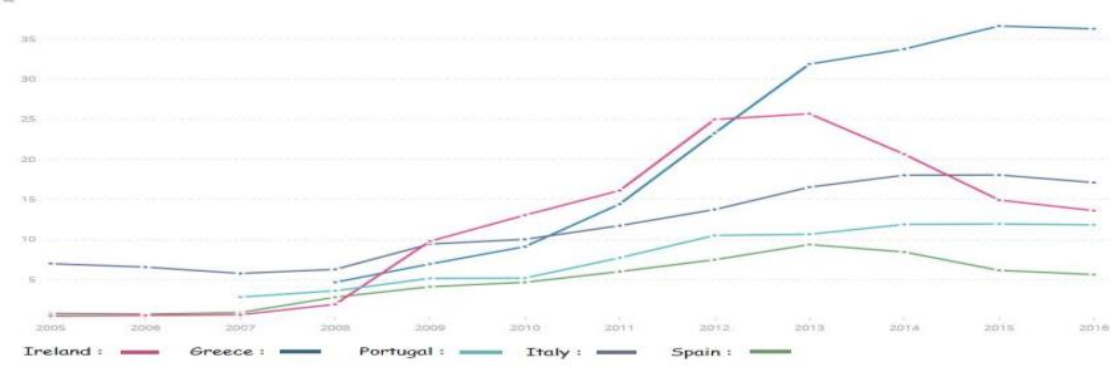

Source: World Bank database, 2018. 